\title{
Aspiration thrombectomy prior to percutaneous coronary intervention in ST-elevation myocardial infarction: a systematic review and meta-analysis
}

\author{
Regina El Dib ${ }^{1,2}$, Frederick Alan Spencer ${ }^{3 *}$, Erica Aranha Suzumura ${ }^{4}$, Huda Gomaa ${ }^{5}$, Joey Kwong ${ }^{6}$, \\ Gordon Henry Guyatt ${ }^{7,8}$ and Per Olav Vandvik ${ }^{9,10}$
}

\begin{abstract}
Background: Trials of aspiration thrombectomy (AT) prior to primary percutaneous intervention (PCI) in patients with ST-segment elevation MI (STEMI) have shown apparently inconsistent results and therefore generated uncertainty and controversy. To summarize the effects of AT prior to PCI versus conventional PCI in STEMI patients.

Methods: Searches of MEDLINE, EMBASE and CENTRAL to June 2015 and review of reference lists of previous reviews. We included randomized controlled trials (RCTs) comparing AT prior to $\mathrm{PCl}$ with conventional $\mathrm{PCl}$ alone. Pairs of reviewers independently screened eligible articles; extracted data; and assessed risk of bias. We used the GRADE approach to rate overall certainty of the evidence.

Results: Among 73 potential articles identified, 20 trials including 21,660 patients were eligible; data were complete for 20,866 patients. Moderate-certainty evidence suggested a non statistically significant decrease in overall mortality (risk ratio (RR) $0.89,95 \%$ confidence interval, 0.78 to 1.01, risk difference (RD) 4/1,000 over 6 months), no impact on recurrent $\mathrm{Ml}$ (RR 0.94, $95 \% \mathrm{Cl}, 0.79$ to 1.12) or major bleeding (RR 1.02, $95 \% \mathrm{Cl}, 0.78$ to 1.35), and an increase in stroke (RR 1.56, $95 \% \mathrm{Cl}, 1.09$ to 2.24, RD 3/1,000 over 6 months).

Conclusions: Moderate certainty evidence suggests aspiration thrombectomy is associated with a possible small decrease in mortality (4 less deaths/1000 over 6 months) and a small increase in stroke (3 more strokes/1000 over 6 months). Because absolute effects are very small and closely balanced, thrombectomy prior to primary PCl should not be used as a routine strategy.
\end{abstract}

Keywords: Myocardial infarction, Aspiration thrombectomy, GRADE, Systematic review, Meta-analysis

\section{Background}

In patients with ST-segment elevation myocardial infarction (STEMI), primary percutaneous coronary intervention (PCI) rapidly restores myocardial flow resulting in decreased infarct size and decreased mortality compared to thrombolysis or conservative medical management [1]. Some patients may, however, experience distal embolization of thrombus and plaque debris with failure to adequately restore distal microcirculatory flow. This

\footnotetext{
* Correspondence: fspence@mcmaster.ca

${ }^{3}$ Division of Cardiology, Department of Medicine, McMaster University, St. Joseph's Healthcare - 50 Charlton Avenue East, Hamilton, Ontario, Canada Full list of author information is available at the end of the article
}

"no reflow" phenomenon is associated with an increase in infarct size and lower survival [2].

Randomized clinical trials (RCTs) comparing aspiration or mechanical thrombectomy prior to primary $\mathrm{PCI}$ to $\mathrm{PCI}$ alone have shown improvement in markers of myocardial reperfusion (e.g. "myocardial blush", ST-segment resolution post procedure) [3]. A recent meta-analysis of $20 \mathrm{RCTs}$ addressing patient-important outcomes and including over 11,000 patients reported that aspiration thrombectomy prior to primary PCI was associated with a reduction in major coronary adverse events and 1-year mortality [4]. A more recent meta-analysis including 26 RCTs, reported a different conclusion: aspiration thrombectomy did not 
improve clinical outcomes [5]. Neither of these metaanalyses included the recently published Trial of Routine Aspiration Thrombectomy with PCI versus PCI Alone in Patients with STEMI (TOTAL), which randomized over 10,000 patients [6].

We therefore undertook a systematic review of all RCTs comparing aspiration thrombectomy prior to PCI versus $\mathrm{PCI}$ alone in patients with STEMI, focusing on patient-important outcomes. As composite endpoints varied between trials and can produce misleading results $[7,8]$, we focused on individual endpoints of overall mortality, recurrent MI, stroke, and major bleeding.

\section{Methods}

This review adheres to the Preferred Reporting Items for Systematic Reviews and Meta-analyses (PRISMA) Statement [9]; the Quality of Reporting of Meta-analyses QUOROM [10]; and the Cochrane Handbook for Systematic Reviews of Interventions [11].

\section{Eligibility criteria}

We included RCTs that compared aspiration thrombectomy prior to PCI with conventional PCI in patients with STEMI, included any one of the following patientimportant outcomes: overall mortality, cardiovascular (CV) mortality, myocardial infarction (MI), stroke (including ischemic and hemorrhagic stroke) and, non-fatal extracranial major bleeding, and followed patients for at least 30 days. We excluded studies reported only as conference abstracts.

\section{Data source and searches}

A previous review with similar inclusion criteria identified studies up to December 2013 [5]. Using Medical Subject Headings (MeSH) based on the terms "thrombectomy," "thrombus aspiration," "thromboaspiration," "infarction," and "myocardial infarction" (Appendix Table 1) we replicated the search strategy of that review [5] for Medline, EMBASE, and Cochrane Controlled Trials Register (CENTRAL) from January 1, 2014 to June 26,2015 . We also reviewed reference lists of relevant review articles $[4,5,12]$ and primary studies.

\section{Selection of studies}

Teams of two reviewers independently screened all titles and abstracts identified by the literature search, obtained full-text articles of all potentially eligible studies, and evaluated these studies for eligibility criteria.

\section{Data extraction and risk of bias assessment}

Three pairs of reviewers independently extracted the following data using a pre-standardized data extraction form: characteristics of the study design; participants; interventions; outcomes event rates and follow-up.
Reviewers independently assessed risk of bias by using a modified version of the Cochrane Collaboration's tool for assessing risk for bias tool [13] (http:/distillercer.com/resources/) [14] that includes nine domains: adequacy of sequence generation, allocation sequence concealment, blinding of participants and caregivers, blinding of data collectors, blinding for outcome assessors, blinding of data analysts, incomplete outcome data, selective outcome reporting, and the presence of other potential sources of bias not accounted for in the previously cited domains [14]. For incomplete outcome data we stipulated as low risk of bias loss to follow-up of less than $10 \%$ and a difference of less than $5 \%$ in missing data in intervention and control groups.

\section{Certainty of evidence}

The reviewers used the Grading of Recommendations Assessment, Development and Evaluation (GRADE) methodology to rate certainty of the evidence for each outcome as high, moderate, low, or very low [15]. Detailed GRADE guidance was used to assess overall risk of bias [16], imprecision [17], inconsistency [18], indirectness [19] and publication bias [20], and summarized results in an evidence profile. We assessed publication bias through visual inspection of funnel plots for 10 or more studies.

For decisions regarding eligibility, risk of bias assessment, and data abstraction, reviewers resolved disagreement through discussion with third party adjudication if necessary.

\section{Data synthesis and statistical analysis}

We chose six months as a follow-up time that represented duration important to patients, sufficient to include most events that would likely be influenced by thrombectomy, and would include relatively few events that would not be potentially influenced by thrombectomy. For meta-analyses we used six months data if available; and otherwise we chose the time point closest to six months, but preferring 1-year over 30 days.

We calculated pooled risk ratios (RRs) and associated $95 \%$ confidential intervals (CIs) using random-effects models with statistical method of Mantel-Haenszel. Absolute effects and $95 \%$ CI were calculated by multiplying pooled RRs and $95 \% \mathrm{CI}$ by baseline risk estimates derived from the TOTAL study (the most recent and largest of the included RCTs) [6]. We addressed variability in results across studies by using $\mathrm{I}^{2}$ statistic and the $\mathrm{P}$ value obtained from the Cochran chi square test. Our primary analyses were based on eligible patients who had reported outcomes for each study (complete case 
analysis). For overall mortality we used all-cause mortality when available. For studies that did not present all-cause mortality we used cardiovascular mortality. We assessed publication bias through visual inspection of funnel plots for outcomes addressed in 10 or more studies. Review Manager (RevMan) provided the software for all analyses (version 5.3; Nordic Cochrane Centre, Cochrane) [21].

We also performed a meta-regression with a fixedeffect model using restricted estimated maximum likelihood with an observed log-odds ratio to predict whether mortality and recurrent myocardial infarction rates changed significantly by mean age. Meta-regression analysis was performed using Stata-13 (StataCorp LP, College Station, TX).

\section{Results}

\section{Selection of titles}

Our search strategy focusing on publications since the last review identified 103 unique citations (Fig. 1).
After title and abstract screening, we assessed the full-text version of 38 relevant citations. In addition, we identified 42 potentially eligible publications included in previous systematic reviews, six [6, 22-26] of which were also identified in our search strategy. Thereafter, we assessed eligibility of 74 unique publications and excluded 49 studies (Fig. 1). As a result, we included 25 publications documenting 20 randomized controlled trials [6, 25-48] involving 21,660 participants. Two studies $[28,35]$ and one updated follow-up [46] were not included in any of the previous reviews.

\section{Study characteristics}

Ten studies $[26,27,29,31-34,39-41,43-46]$ were conducted largely in Europe (Table 1). Sample size ranged from 56 [35] to 10,732 [6] patients of whom a majority were males with mean ages typically in the early 60s. Studies included adult STEMI patients typically with symptoms lasting $>30 \mathrm{~min}$ but $<12$ hours, and cumulative ST-segment elevation of

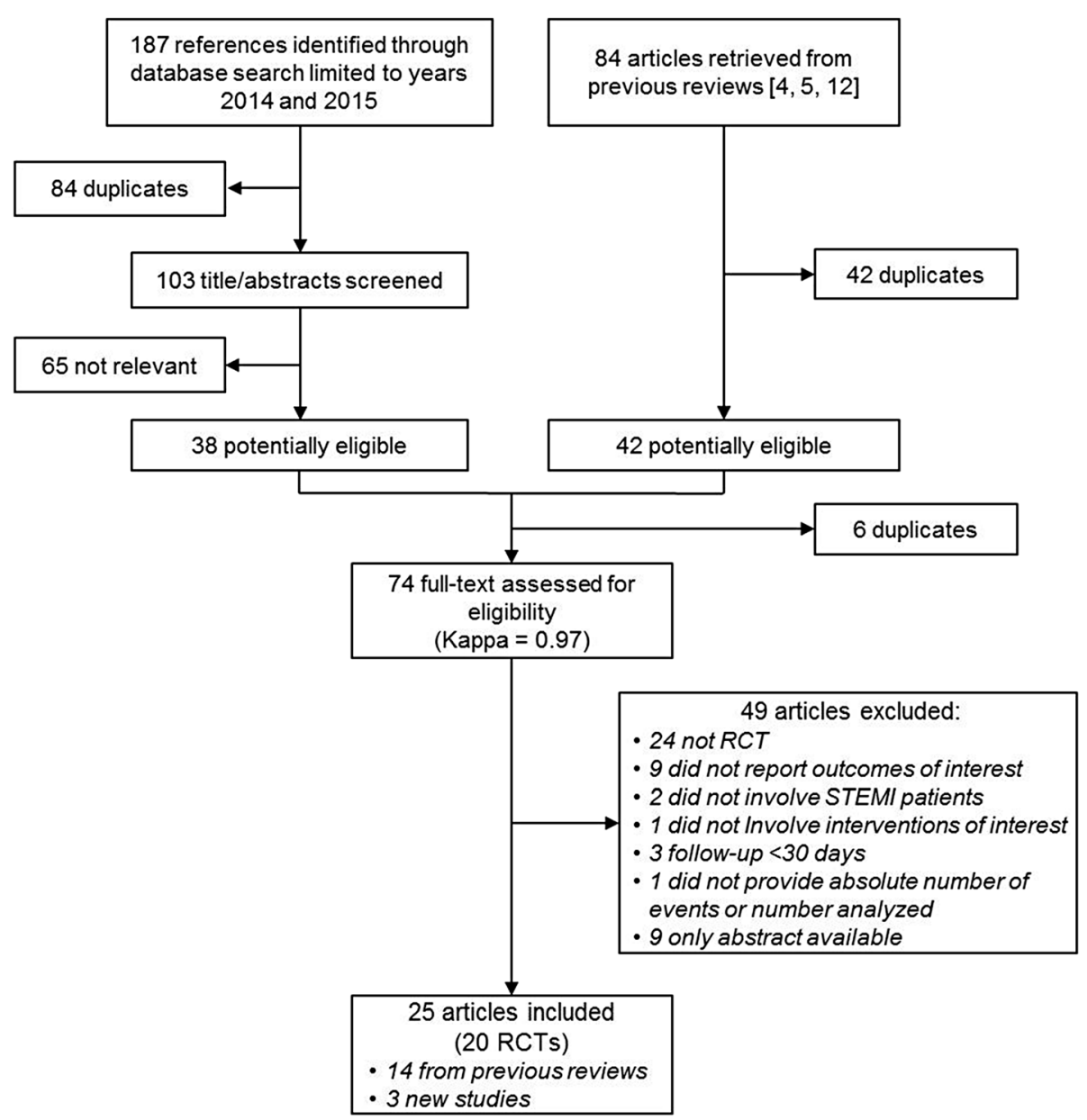

Fig. 1 Flowchart of the review 
Table 1 Study characteristics

\begin{tabular}{|c|c|c|c|c|c|c|}
\hline Author, year & Location & $\begin{array}{l}\text { No. } \\
\text { patient }\end{array}$ & Mean age (SD) & No. male (\%) & Inclusion criteria & Exclusion criteria \\
\hline \multirow[t]{2}{*}{ ADMIT [28] } & \multirow[t]{2}{*}{ Haifa, Israel } & \multirow[t]{2}{*}{100} & $I=57.5(12.4)$ & \multirow[t]{2}{*}{$86(86.0)$} & \multirow{2}{*}{$\begin{array}{l}\text { Admission }<12 \text { hours of onset of } \\
\text { symptoms of STEMI, regardless of } \\
\text { the initial TIMI flow }\end{array}$} & \multirow{2}{*}{$\begin{array}{l}\text { Inability to consent; known allergy to } \\
\text { either aspirin or clopidogrel; life } \\
\text { expectancy < } 6 \text { months; cardiogenic } \\
\text { shock }\end{array}$} \\
\hline & & & $C=57.2(12.1)$ & & & \\
\hline \multirow[t]{2}{*}{ Bulum 2012 [29] } & \multirow{2}{*}{$\begin{array}{l}\text { Zagreb, } \\
\text { Croatia }\end{array}$} & \multirow[t]{2}{*}{60} & $I=54.3(9.7)$ & \multirow[t]{2}{*}{$47(78.3)$} & \multirow{2}{*}{$\begin{array}{l}\text { Symptoms suggesting acute } \\
\text { myocardial ischemia of }>20 \text { min, } \\
\text { time from symptom onset of } \\
<12 \text { hours, and ST-segment elevation } \\
>0.1 \mathrm{mV} \text { in }>2 \text { contiguous ECG leads }\end{array}$} & \multirow{2}{*}{$\begin{array}{l}\text { Need for rescue PCI after failed } \\
\text { thrombolysis; cardiogenic shock; } \\
\text { triple-vessel disease; significant LMCA } \\
\text { stenosis; previous PCl of an IRA; pre- } \\
\text { vious CABG; life expectancy } \\
<6 \text { months }\end{array}$} \\
\hline & & & $C=58.5(8.6)$ & & & \\
\hline \multirow[t]{2}{*}{ Chao 2008 [30] } & \multirow{2}{*}{$\begin{array}{l}\text { Taipei City, } \\
\text { Taiwan }\end{array}$} & \multirow[t]{2}{*}{74} & $\mathrm{I}=60(13)$ & \multirow[t]{2}{*}{$63(85.1)$} & \multirow{2}{*}{$\begin{array}{l}\text { STEMI (typical chest pain }>30 \text { min } \\
\text { with new ST-segment elevation } \\
\geq 0.1 \mathrm{mV} \text { in }>2 \text { contiguous leads on } \\
\text { a } 12 \text {-lead ECG), }<12 \text { hours after } \\
\text { onset, and eligible for primary PCl }\end{array}$} & \multirow{2}{*}{$\begin{array}{l}\text { Killip IV hemodynamic status; } \\
\text { ventricular tachyarrhythmias; } \\
\text { previous CABG or significant LMCA } \\
\text { lesion; culprit vessel diameter } \\
<2 \text { mm; existing TIMI } 3 \text { flow without } \\
\text { visible thrombus in IRA }\end{array}$} \\
\hline & & & $C=62(11)$ & & & \\
\hline \multirow{2}{*}{$\begin{array}{l}\text { De Luca } 2006 \\
\text { [31] }\end{array}$} & \multirow[t]{2}{*}{ Rome, Italy } & \multirow[t]{2}{*}{76} & $I=66.7(14.1)$ & \multirow[t]{2}{*}{$48(63.2)$} & \multirow{2}{*}{$\begin{array}{l}\text { Anterior STEMI, }>18 \text { years old, and } \\
\text { have an identifiable thrombus on } \\
\text { IRA at coronary angiography }\end{array}$} & \multirow{2}{*}{$\begin{array}{l}\text { Previous MI or CABG; triple-vessel } \\
\text { disease; severe valvar disease; TIMI } 2 \\
\text { or } 3 \text { flow at the time of initial } \\
\text { angiography; unsuccessful PCI } \\
\text { defined as no antegrade flow or } \\
>50 \% \text { residual stenosis in the IRA }\end{array}$} \\
\hline & & & $C=64.6(12.5)$ & & & \\
\hline \multirow[t]{2}{*}{ EXPIRA $[32,33]$} & \multirow[t]{2}{*}{ Rome, Italy } & \multirow[t]{2}{*}{175} & $I=66.7(14.1)$ & \multirow[t]{2}{*}{$105(60.0)$} & \multirow{2}{*}{$\begin{array}{l}\text { First STEMI, }<9 \text { hours from } \\
\text { symptoms onset, IRA } \geq 2.5 \mathrm{~mm} \text { in } \\
\text { diameter, thrombus score } \geq 3 \text {, TIMI } \\
\text { flow } \leq 1 \text {, and }>18 \text { years old }\end{array}$} & \multirow{2}{*}{$\begin{array}{l}\text { Previous PCI on IRA; previous CABG; } \\
\text { cardiogenic shock; triple-vessel disease; } \\
\text { LMCA disease; severe valvular disease; } \\
\text { thrombolysis; contraindication to } \\
\text { glycoprotein IIb/llla inhibitors }\end{array}$} \\
\hline & & & $C=64.6(12.5)$ & & & \\
\hline \multirow[t]{2}{*}{ EXPORT [34] } & \multirow{2}{*}{$\begin{array}{l}24 \text { centres in } \\
\text { India and } \\
\text { Europe }\end{array}$} & \multirow[t]{2}{*}{249} & $I=59.2(12.8)$ & \multirow[t]{2}{*}{$202(81.1)$} & \multirow{2}{*}{$\begin{array}{l}>18 \text { years old, STEMI }<12 \text { hours of } \\
\text { symptom onset, ST-segment elevation } \\
\geq 2 \mathrm{~mm} \text { in } \geq 2 \text { contiguous leads, visual } \\
\text { reference vessel diameter }>2.5 \mathrm{~mm} \text {, and } \\
\text { with TIMl flow of } 0 \text { or } 1 \text { before placing } \\
\text { the wire in the IRA }\end{array}$} & \multirow{2}{*}{$\begin{array}{l}\text { Cardiogenic shock; cardiac arrest } \\
\text { prior to intervention; pre- } \\
\text { catheterization therapy with Iytic } \\
\text { agents, or with glycoprotein llb/llla } \\
\text { inhibitors, or with pacemakers; life } \\
\text { expectancy }<1 \text { year; current } \\
\text { participation in other investigations }\end{array}$} \\
\hline & & & $C=61.2(12.9)$ & & & \\
\hline IMPACT [35] & Cambridge, UK & 56 & $\begin{array}{l}I=64.9(11.2) \\
C=67.2(11.6)\end{array}$ & $31(55.3)$ & $\begin{array}{l}>18 \text { and }<90 \text { years old, ability to } \\
\text { give informed consent, STEMI (ST- } \\
\text { segment elevation } \geq 2 \mathrm{~mm} \text { in } \geq 2 \\
\text { contiguous chest leads or } \geq 1 \mathrm{~mm} \text { in } \\
\geq 2 \text { contiguous limb leads) or new } \\
\text { LBBB, chest pain for }<12 \text { hours, } \\
\text { restoration of at least TIMl } 1 \text { flow } \\
\text { after the wire crossed the occlusion }\end{array}$ & $\begin{array}{l}\text { Cardiogenic shock; previous MI in } \\
\text { the IRA territory; unfavourable } \\
\text { anatomy (LMCA occlusion or distal } \\
\text { vessel occlusion); severe asthma or } \\
\text { bradycardia precluding use of } \\
\text { adenosine; women of childbearing } \\
\text { age; life expectancy < } 3 \text { months }\end{array}$ \\
\hline
\end{tabular}

Follow-up time Outcomes evaluated

\section{Quality of epicardial and \\ microcirculation perfusion; LV}

regurgitation; MACE (death, recurrent MI, TVR)

Referent vessel diameter; minimal

lumen diameter; lesion length;

percentage of diameter stenosis; MACE

(death, recurrent Ml, stroke, TLR)

6 months

LV remodeling; MACE (death,

recurrent MI, hospitalization for HF)

9 months

Final $M B G \geq 2$; rate of 90-min STsegment resolution $>70 \%$; MACE (cardiac death, recurrent MI, TVR); stent thrombosis

1 month

Reperfusion (rate of ST-segment resolution $>50 \%$ at 60 minutes postprocedure or MBG 3 immediately postprocedure); magnitude of

ST-segment resolution; improvement in TIMI flow; corrected TIMI frame count; MACE (death, recurrent Ml, emergent CABG, TLR or TVR, stroke); rate of distal embolization; rate of required bailout techniques (rescue use of the aspiration catheter, distal protection, or glycoprotein Ilb/llla inhibitors)

6 months Index of microcirculatory resistence; MACE (all-cause death or MI) 
Table 1 Study characteristics (Continued)

\begin{tabular}{|c|c|c|c|c|c|c|c|c|}
\hline \multirow{2}{*}{$\begin{array}{l}\text { INFUSE-AMI } \\
{[36,37]}\end{array}$} & \multirow{2}{*}{$\begin{array}{l}37 \text { sites in } 6 \\
\text { countries }\end{array}$} & \multirow[t]{2}{*}{452} & $\mathrm{I}=61(\mathrm{NR})$ & \multirow[t]{2}{*}{$334(73.9)$} & \multirow{2}{*}{$\begin{array}{l}\geq 18 \text { years old, STEMI with } \geq 1 \mathrm{~mm} \text { of } \\
\text { ST-segment elevation in } \geq 2 \text { contiguous } \\
\text { leads in V1 through } \mathrm{V} 4 \text { or new LBBB } \\
\text { with anticipated symptom onset to } \\
\text { device time of } \leq 5 \text { hours }\end{array}$} & \multirow[b]{2}{*}{$\begin{array}{l}\text { Prior MI, CABG or LAD stenting; } \\
\text { contraindications to study } \\
\text { medications, contrast or CMRI; } \\
\text { creatinine clearance }<30 \mathrm{~mL} / \mathrm{min} \text { per } \\
1.73 \mathrm{~m}^{2} \text { or dialysis; platelet count } \\
<100,000 \text { or }>700,000 \mathrm{cell} / \mathrm{s} / \mathrm{mm}^{3} ; \\
\text { hemoglobin }<10 \mathrm{~g} / \mathrm{dL} \text {; recent major } \\
\text { bleeding; bleeding diathesis; current } \\
\text { warfarin use; intracranial disease, } \\
\text { stroke or TIA within } 6 \text { months or any } \\
\text { neurological defect; cardiogenic } \\
\text { shock; prior fibrinolysis or } \\
\text { glycoprotein IIb/Illa inhibitors for the } \\
\text { present admission; any comorbid } \\
\text { likely to interfere with protocol } \\
\text { compliance or associated with } \\
<1 \text { year survival }\end{array}$} & \multirow[t]{2}{*}{12 months } & \multirow{2}{*}{$\begin{array}{l}\text { Infarct size measured as a } \\
\text { percentage of LV mass at } 30 \text { days. } \\
\text { MACE (death, recurrent MI, new- } \\
\text { onset severe HF, re-hospitalization for } \\
\text { HF, stroke, clinically driven TVR) }\end{array}$} \\
\hline & & & $C=60$ (NR) & & & & & \\
\hline \multirow[t]{2}{*}{ ITTI [38] } & \multirow{2}{*}{$\begin{array}{l}\text { Kaohsiung } \\
\text { City, Yun-Lin } \\
\text { Branch, Taiwan }\end{array}$} & \multirow[t]{2}{*}{100} & $I=60.4(11.9)$ & \multirow[t]{2}{*}{$86(86.0)$} & \multirow{2}{*}{$\begin{array}{l}\geq 18 \text { years old, continuous } \\
\text { chest pain } \geq 30 \mathrm{~min}, \mathrm{ST} \text {-segment } \\
\text { elevation }>0.1 \mathrm{mV} \text { in } \geq 2 \text { contiguous } \\
\text { leads on a } 12 \text {-lead ECG }\end{array}$} & \multirow{2}{*}{$\begin{array}{l}\text { Cardiogenic shock (systolic BP > } \\
80 \mathrm{mmHg} \text { or need for inotropic } \\
\text { agent); history of bleeding tendency, } \\
\text { major operation within } 6 \text { weeks; } \\
\text { hepatic or renal insufficiency; } \\
\text { contraindication to tirofiban use }\end{array}$} & \multirow[t]{2}{*}{6 months } & \multirow{2}{*}{$\begin{array}{l}\text { Occurrence of MBG 3; complete ST- } \\
\text { segment resolution; procedure time; } \\
\text { occurrence of no-reflow; CK-MB peak } \\
\text { and time to peak; TIMI flow and } \\
\text { corrected TIMI frame count; MACE } \\
\text { (death, recurrent MI, TLR, stroke) }\end{array}$} \\
\hline & & & $C=56.5(11.9)$ & & & & & \\
\hline \multirow[t]{2}{*}{ Kaltoft 2006 [39] } & \multirow{2}{*}{$\begin{array}{l}\text { Aarhus, } \\
\text { Denmark }\end{array}$} & \multirow[t]{2}{*}{215} & $I=65(11)$ & \multirow[t]{2}{*}{$168(78.1)$} & \multirow{2}{*}{$\begin{array}{l}\text { STEMI, symptoms lasting }>30 \mathrm{~min} \\
\text { but }<12 \text { hours, and cumulative } \\
\text { ST-segment elevation of } \geq 2 \mathrm{mV} \text { in } \\
\geq 2 \text { contiguous leads }\end{array}$} & \multirow{2}{*}{$\begin{array}{l}\text { LBBB; MI within the previous } 30 \text { days; } \\
\text { fibrinolytic treatment; previous CABG; } \\
\text { LCA stenosis; need for mechanical } \\
\text { ventilation; severe HF treated with } \\
\text { intra-aortic balloon pump }\end{array}$} & \multirow[t]{2}{*}{1 month } & \multirow[b]{2}{*}{$\begin{array}{l}\text { Myocardial salvage estimated by } \\
\text { 99mTC-sestamibi SPECT; final infarct } \\
\text { size; markers of effective reperfusion } \\
\text { (TIMI flow, corrected TIMI frame } \\
\text { count, ST-segment resolution } \\
\text { immediately, } 90 \text { min and } 6 \text { hours } \\
\text { after PCI); release of TnT; distal } \\
\text { embolization visible at the end of } \\
\text { PCl; total procedure time; MACE } \\
\text { (death, recurrent MI, disabling stroke); } \\
\text { LVEF after } 30 \text { days; technical success } \\
\text { of the thrombectomy }\end{array}$} \\
\hline & & & $C=63(13)$ & & & & & \\
\hline \multirow[t]{2}{*}{ Liistro 2009 [40] } & \multirow[t]{2}{*}{ Arezzo, Italy } & \multirow[t]{2}{*}{111} & $I=64(11)$ & \multirow[t]{2}{*}{$86(77.5)$} & \multirow{2}{*}{$\begin{array}{l}\text { STEMI with symptoms lasting } \\
>30 \text { minutes and }<12 \text { hours, } \\
\text { ST-segment elevation }>0.1 \mathrm{mV} \text { in } \geq 2 \\
\text { leads on the ECG }\end{array}$} & \multirow{2}{*}{$\begin{array}{l}\text { Contraindication to the use of } \\
\text { platelet glycoprotein Ilb/llla } \\
\text { inhibitors; rescue PCl after } \\
\text { thrombolysis; previous Ml; absence of } \\
\text { optimal echocardiographic apical } \\
\text { view; life expectancy }<6 \text { months; lack } \\
\text { of informed consent }\end{array}$} & \multirow[t]{2}{*}{6 months } & \multirow{2}{*}{$\begin{array}{l}\text { Rate of ST-segment resolution } \geq 70 \% \text {; } \\
\text { TIMI } 3 \text { grade flow; corrected TIMl frame } \\
\text { count; myocardial contrast echocardiog- } \\
\text { raphy score index; absence of persistent } \\
\text { ST-segment deviation; time course of } \\
\text { wall-motion score index; LVEF; LV } \\
\text { volume; death; recurrent MI; LV failure; } \\
\text { new revascularization }\end{array}$} \\
\hline & & & $C=65(11)$ & & & & & \\
\hline \multirow[t]{2}{*}{ REMEDIA [41] } & \multirow[t]{2}{*}{ Rome, Italy } & \multirow[t]{2}{*}{99} & $I=61(13)$ & \multirow[t]{2}{*}{83 (83.3) } & \multirow{2}{*}{$\begin{array}{l}<12 \text { hours of onset of STEMI referred } \\
\text { for primary or rescue PCI }\end{array}$} & \multirow{2}{*}{$\begin{array}{l}\text { No angiographic exclusion criteria } \\
\text { were adopted }\end{array}$} & \multirow[t]{2}{*}{1 month } & \multirow[b]{2}{*}{$\begin{array}{l}\text { MBG } \geq 2 \text {; rate of ST-segment resolution } \\
\geq 70 \% \text {; peak CK-MB; direct stenting rate; } \\
\text { distal embolization rate (abrupt "cutoff" } \\
\text { occlusion of a distal branch); composite } \\
\text { of distal embolization, slow-flow (TIMI } \\
\text { flow grade 2), no-reflow (TIMI flow } \\
\text { grade } 0 \text { to 1); death; recurrent MI; stroke; } \\
\text { TLR; any major adverse event }\end{array}$} \\
\hline & & & $C=60(13)$ & & & & & \\
\hline
\end{tabular}


Table 1 Study characteristics (Continued)

\begin{tabular}{|c|c|c|c|c|c|c|c|c|}
\hline \multirow{2}{*}{$\begin{array}{l}\text { Shehata } 2014 \\
\text { [25] }\end{array}$} & \multirow[t]{2}{*}{ Cairo, Egypt } & \multirow[t]{2}{*}{100} & $I=60.32(9.2)$ & \multirow[t]{2}{*}{$64(64)$} & \multirow{2}{*}{$\begin{array}{l}\text { Diabetic patients suffering from } \\
\text { acute STEMI, symptoms lasting } \\
>30 \text { minutes and }<12 \text { hours before } \\
\text { admission, and ST-segment elevation } \\
\text { of }>0.1 \mathrm{mV} \text { in } \geq 2 \text { leads }\end{array}$} & \multirow{2}{*}{$\begin{array}{l}\text { Need for rescue } \mathrm{PCl} \text { after } \\
\text { thrombolysis; prior history of } \\
\text { unstable angina or Ml; prior PCI } \\
\text { CABG; congenital heart disease or } \\
\text { any myocardial disease apart from } \\
\text { ischemia; limited life expectancy due } \\
\text { to coexistent disease }\end{array}$} & \multirow[t]{2}{*}{8 months } & \multirow{2}{*}{$\begin{array}{l}\text { In-stent restenosis (angiographic } \\
\text { luminal diameter stenosis by }>50 \% \\
\text { in quantitative coronary } \\
\text { angiography); MACE (death due to } \\
\text { cardiac cause, nonfatal Ml, TLR) }\end{array}$} \\
\hline & & & $C=59.4(7.4)$ & & & & & \\
\hline \multirow[t]{2}{*}{ Sim 2013 [42] } & \multirow{2}{*}{$\begin{array}{l}\text { Gwangju, } \\
\text { Republic of } \\
\text { Korea }\end{array}$} & \multirow[t]{2}{*}{86} & $\mathrm{I}=63(\mathrm{NR})$ & \multirow[t]{2}{*}{$59(71.1)$} & \multirow{2}{*}{$\begin{array}{l}\text { STEMI with onset of symptoms } \\
<12 \text { hours, coronary artery lesions } \\
\text { with visible thrombus, ability to } \\
\text { undergo a complete CCT } \\
\text { examination (Killip I and II) with the } \\
\text { ability to perform a15-second } \\
\text { breath-hold }\end{array}$} & \multirow{2}{*}{$\begin{array}{l}\text { Previous MI or CABG; cardiogenic } \\
\text { shock; LMCA disease; severe valvular } \\
\text { heart disease; unsuccessful PCI } \\
\text { (post-PCI TIMI flow }<2 \text { or } \geq 50 \% \\
\text { residual stenosis in IRA); rescue or } \\
\text { facilitated PCl; contraindication to } \\
\text { glycoprotein Ilb/llla inhibitors }\end{array}$} & \multirow[t]{2}{*}{12 months } & \multirow{2}{*}{$\begin{array}{l}\text { Infarct size at } 2 \text { months; markers of } \\
\text { myocardial reperfusion (TIMI flow, } \\
\text { MBG, ST-segment resolution rate at } \\
90 \text { min); LV function and volumes at } \\
2 \text { months; MACE (cardiac death, MI, } \\
\text { TVR) }\end{array}$} \\
\hline & & & $C=60(N R)$ & & & & & \\
\hline \multirow[t]{2}{*}{$\operatorname{TAPAS}[43,44]$} & \multirow{2}{*}{$\begin{array}{l}\text { Groningen, The } \\
\text { Netherlands }\end{array}$} & \multirow[t]{2}{*}{1071} & $I=63(13)$ & \multirow[t]{2}{*}{$755(70.5)$} & \multirow{2}{*}{$\begin{array}{l}\text { STEMl, symptoms }>30 \text { minutes and } \\
<12 \text { hours, and ST-segment elevation } \\
\text { of } \geq 0.1 \mathrm{mV} \text { in } \geq 2 \text { leads }\end{array}$} & \multirow{2}{*}{$\begin{array}{l}\text { Rescue PCl after thrombolysis; life } \\
\text { expectancy }<6 \text { months; lack of } \\
\text { informed consent }\end{array}$} & \multirow[t]{2}{*}{1 month } & \multirow{2}{*}{$\begin{array}{l}\text { Rate of post-procedural MBG of 0; } \\
\text { rate of TIMI flow grade of 3; } \\
\text { complete resolution of ST-segment } \\
\text { elevation; absence of persistent } \\
\text { ST-segment deviation; TVR; recurrent } \\
\text { MI; death }\end{array}$} \\
\hline & & & $C=63(13)$ & & & & & \\
\hline \multirow[t]{2}{*}{ TASTE $[26,27]$} & \multirow{2}{*}{$\begin{array}{l}29 \text { centers in } \\
\text { Sweden, } 1 \\
\text { center in } \\
\text { lceland and } 1 \text { in } \\
\text { Denmark }\end{array}$} & \multirow[t]{2}{*}{7244} & $I=66.5(11.5)$ & \multirow[t]{2}{*}{$5424(74.9)$} & \multirow{2}{*}{$\begin{array}{l}\text { STEMI, chest pain for }>30 \text { minutes and } \\
<24 \text { hours, ST-segment elevation in } \geq 2 \\
\text { contiguous leads ( } \geq 0.2 \mathrm{mV} \text { in lead V2 } \\
\text { or V3 or } \geq 0.1 \mathrm{mV} \text { in other leads) or a } \\
\text { presumably new LBBB, and a } \\
\text { corresponding culprit-artery lesion } \\
\text { on angiography }\end{array}$} & \multirow{2}{*}{$\begin{array}{l}\text { Need for emergency CABG; inability } \\
\text { to provide oral informed consent; } \\
<18 \text { years old; previously randomized } \\
\text { in the study }\end{array}$} & \multirow[t]{2}{*}{12 months } & \multirow{2}{*}{$\begin{array}{l}\text { MACE (all-cause mortality; } \\
\text { rehospitalization for Ml; stent } \\
\text { thrombosis); TVR; TLR; complications } \\
\text { of PCI, stroke or neurologic } \\
\text { complications, HF and length of stay } \\
\text { during index hospitalization }\end{array}$} \\
\hline & & & $C=65.9(11.7)$ & & & & & \\
\hline \multirow[t]{2}{*}{ TOTAL [6] } & \multirow{2}{*}{$\begin{array}{l}87 \text { hospitals in } \\
20 \text { countries }\end{array}$} & \multirow[t]{2}{*}{10732} & $I=61.0(11.8)$ & \multirow[t]{2}{*}{$7797(72.6)$} & \multirow{2}{*}{$\begin{array}{l}\text { Symptoms of Ml lasting for } \geq 30 \text { min, } \\
\text { definite ECG changes indicating } \\
\text { STEMI, referred for PCI for presenting } \\
\text { symptoms, randomized within } \\
12 \text { hours of symptoms onset and } \\
\text { before diagnostic angiography, } \\
\text { Informed consent }\end{array}$} & \multirow{2}{*}{$\begin{array}{l}\leq 18 \text { years old; prior CABG; life } \\
\text { expectancy }<6 \text { months due to } \\
\text { noncardiac condition; treatment with } \\
\text { fibrinolytic therapy for qualifying } \\
\text { index STEMI event }\end{array}$} & \multirow[t]{2}{*}{6 months } & MACE (cardiovascular death, \\
\hline & & & $C=65.0(11.9)$ & & & & & $\begin{array}{l}\text { recurrent MI, cardiogenic shock, HF } \\
\text { NYHA class IV); stroke }\end{array}$ \\
\hline TROFI $[45,46]$ & 5 european & 141 & $I=61.1(11.8)$ & $102(72.3)$ & $\geq 18$ years old, STEMI documented & Pregnancy; known intolerance to & 12 months & Minimum flow area immediately \\
\hline & & & $C=60.9(12.7)$ & & $\begin{array}{l}\text { in } \geq 2 \text { contiguous leads prior to } \mathrm{PCl} \text {, } \\
\text { presenting in the cath lab }<12 \text { hours } \\
\text { after the onset of symptoms lasting } \\
\geq 20 \text { min and having an angiographically } \\
\text { visible stenosis ( }>30 \% \text { or } \mathrm{TMMI} \leq \| 1 \text { in a } \\
\text { single de novo, native, previously } \\
\text { unstented vessel }\end{array}$ & $\begin{array}{l}\text { diameter stenosis <30\% in the target } \\
\text { lesion; multi-vessel CAD; unprotected } \\
\text { LMCA stenosis }>30 \% \text {; distal vessel } \\
\text { occlusion; severe tortuous, calcified or } \\
\text { angulated anatomy that would result in } \\
\text { sub-optimal imaging or excessive risk } \\
\text { of complication from insertion of } \\
\text { catheter; fibrinolysis prior to PCl; platelet } \\
<100,000 \text { cells/4l; coagulopathy or active } \\
\text { bleeding or chronic anticoagulation } \\
\text { therapy; cardiogenic shock; significant } \\
\text { comorbidities precluding follow-up as } \\
\text { judged by investigators; major planned } \\
\text { surgery requiring discontinuation of } \\
\text { antiplatelets; proximal RCA stenosis } \\
\text { (>30 \%) if the IRA is mid or distal-RCA }\end{array}$ & & $\begin{array}{l}\text { (cardiac death, recurrent Ml in the } \\
\text { territory of IRA, clinically driven TVR) }\end{array}$ \\
\hline
\end{tabular}


Table 1 Study characteristics (Continued)

\begin{tabular}{|c|c|c|c|c|c|c|c|c|}
\hline \multirow[t]{2}{*}{ VAMPIRE [47] } & \multirow{2}{*}{$\begin{array}{l}23 \text { hospitals in } \\
\text { Japan }\end{array}$} & \multirow[t]{2}{*}{355} & $I=63.2(10.6)$ & \multirow[t]{2}{*}{$281(79.1)$} & \multirow{2}{*}{$\begin{array}{l}\geq 21 \text { years old, STEMI symptom } \\
>30 \text { min but }<24 \text { hours, ST-segment } \\
\text { elevation } \geq 2 \mathrm{~mm} \text { in } \geq 2 \text { contiguous } \\
\text { leads or with a presumably new } \\
\text { LBBB }\end{array}$} & \multirow[b]{2}{*}{$\begin{array}{l}\text { Primary thrombolysis prior to } \\
\text { randomization; cardiogenic shock; } \\
\text { history of cardiac arrest; history of } \\
\text { CABG; chronic renal failure (Cr } \\
>2.0 \mathrm{mg} / \mathrm{dl}) \text { or hemodialysis; } \mathrm{LMCA} \\
\text { disease; target vessel }<2.5 \mathrm{~mm} \text { or } \\
>5 \mathrm{~mm} \text { in diameter }\end{array}$} & \multirow[t]{2}{*}{8 months } & \multirow[b]{2}{*}{$\begin{array}{l}\text { Incidence of slow flow or no reflow } \\
\text { during primary PCI (TIMI flow grade } \\
<3 \text { not attributable to dissection, } \\
\text { occlusive thrombus, or epicardial } \\
\text { spasm); coronary flow and } \\
\text { myocardial perfusion immediately } \\
\text { after PCI (assessed by TIMl flow } \\
\text { grade, corrected TIMl frame count } \\
\text { and MBG); magnitude of ST-segment } \\
\text { resolution, peak CK and CK-MB; } \\
\text { angiographic in-stent late lumen loss } \\
\text { LV function; brain natriuretic peptide } \\
\text { MACE (death, recurrence MI, TLR) }\end{array}$} \\
\hline & & & $C=63.5(9.9)$ & & & & & \\
\hline \multirow[t]{2}{*}{ Yin 2011 [48] } & \multirow[t]{2}{*}{ Dalian, China } & \multirow[t]{2}{*}{164} & $I=63.1(12.9)$ & \multirow[t]{2}{*}{$120(73.2)$} & \multirow[t]{2}{*}{ STEMI patients who had $\mathrm{PCl}$} & \multirow[t]{2}{*}{ Not reported } & \multirow[t]{2}{*}{12 months } & \multirow{2}{*}{$\begin{array}{l}\text { Thrombus score; periprocedural } \\
\text { no-reflow; TIMI frame count; lumen } \\
\text { diameter; stent length; 1-week } \\
\text { post-procedural ejection fraction; } \\
\text { post-procedural angina; recurrent MI; } \\
\text { death }\end{array}$} \\
\hline & & & $C=62.9(9.5)$ & & & & & \\
\hline
\end{tabular}

SD events, $M I$ myocardial infarction, $T V R$ target vessel revascularization, $E C G$ electrocardiogram, $P C l$ percutaneous coronary intervention, $L M C A$ left main coronary artery, IRA infarct-related artery, CABG coronary artery bypass grafting, TLR target lesion revascularization, MBG myocardial blush grade, $H F$ heart failure, LBBB left bundle branch block, NR not reported, LAD left anterior descending, CMRI cardiac magnetic resonance imaging, TIA transient ischemic attack, SPECT single-photon emission computed tomography, TnT troponin T, LVEF left ventricular ejection fraction, CK-MB creatine kinase myocardial band, CCT cardiac computed tomography, NYHA New York Heart Association, CAD coronary artery disease, OFDI optical frequency domain imaging, RCA right coronary artery 
$>0.1 \mathrm{mV}$ in $\geq 2$ leads. Some studies excluded life expectancy $<6$ months $[6,28,29]$; cardiogenic shock [28, 29, 32, 33, 35-38, 45-47]; previous CABG or MI or significant left main coronary lesion [6, 25, 29-33, 35-37, 39, 40, 42, 45-47]; pre-catheterization therapy with lytic agents [34]; severe asthma or bradycardia precluding use of adenosine [35]; dialysis; platelet count $<100,000$ or $>700,000$ cells/mm3; hemoglobin <10 g/dL [36, 37]; severe HF treated with intra-aortic balloon pump [39]; contraindication or prior use of platelet glycoprotein IIb/IIIa inhibitors [32-34, 40, 42]; rescue or facilitated PCI [4244]; need for emergency CABG [26, 27]; pregnancy $[45,46]$; and major planned surgery requiring discontinuation of antiplatelets agents $[45,46]$. Followup time ranged from 30 to 360 days.

Table 2 Study protocol used as preprocedure reported by the included studies

\begin{tabular}{ll}
\hline Author, year & Different regimens of anti-aggregation/anticoagulation used \\
\hline ADMIT [28] & $\begin{array}{l}\text { Oral aspirin } 300 \mathrm{mg} \text { as a loading dose (or only } 100 \mathrm{mg} \text { if the patient was on aspirin therapy) continued by } 100 \mathrm{mg} / \mathrm{day} \\
\text { indefinitely, } 600 \mathrm{mg} \text { clopidogrel loading dose continued by } 75 \mathrm{mg} / \mathrm{day} \text { for one year and IV } 60 \mathrm{mg} / \mathrm{kg} \text { unfractionated heparin } \\
\text { as loading dose to keep activating clotting time during procedure }>250 \text { second. }\end{array}$
\end{tabular}

Bulum 2012 [29] $300 \mathrm{mg}$ of aspirin and $600 \mathrm{mg}$ of clopidogrel and a weight-adjusted dose of unfractionated heparin; the usage of glycoprotein $\mathrm{llb} / \mathrm{lll}$ a inhibitor (eptifibatide) was left to the discretion of the operator.

Chao 2008 [30] Aspirin $300 \mathrm{mg}$ and clopidogrel $300 \mathrm{mg}$ were given as loading dose, with intravenous heparin 70- 100 U/kg to achieve activated clotting time $(A C T)>200$ s prior to intervention.

De Luca 2006 [31] Aspirin $300 \mathrm{mg}$ orally and heparin $8000 \mathrm{IU}$ intravenously before the procedure and abciximab as a $0.25 \mathrm{mg} / \mathrm{kg}$ bolus and $0.125 \mathrm{mg} / \mathrm{kg} / \mathrm{min}$ intravenous infusion immediately before the revascularisation and continued for 12 hours.

EXPIRA [32, 33] Aspirin $300 \mathrm{mg}$, intravenous heparin, abciximab at a standard dose, and clopidogrel $300 \mathrm{mg}$ before the revascularization.

EXPORT [34] The choice of medication during the procedure such as aspirin, heparin, clopidogrel, and glycoprotein Ilb/llla inhibitors was also at the investigator's discretion, and were administrated according to standard hospital procedure.

IMPACT [35] Aspirin $300 \mathrm{mg}$ and clopidogrel $600 \mathrm{mg}$ preloading in the ambulance and anticoagulated with a heparin bolus (70-100 U/kg) after arterial sheath insertion to achieve an activated clotting time (ACT) $>250$ s. Adjunctive pharmacotherapy, including abciximab and bivalirudin, was given at the operator's discretion.

INFUSE-AMI [36, 37] Patients undergoing primary PCI received bivalirudin anticoagulation.

ITTI [38] Aspirin (300 mg loading followed by $100 \mathrm{mg}$ daily) and clopidogrel (300 mg loading followed by 75 mg daily) and unfractionated heparin $100 \mathrm{lU} / \mathrm{kg}$.

Kaltoft 2006 [39] Aspirin 300 mg orally or intravenously, clopidogrel 300 mg orally, and unfractionated heparin 10000 IE intravenously. During the intervention, all patients were treated with abciximab.

Liistro 2009 [40] Aspirin (a loading dose of $500 \mathrm{mg}$ ), heparin (70 IU/ $\mathrm{kg}$ ), and clopidogrel (a loading dose of $600 \mathrm{mg}$ ). All patients also received the glycoprotein Ilb/llla inhibitor abciximab with an intravenous procedural bolus of $0.25 \mathrm{mg} / \mathrm{kg}$ followed by a continuous intravenous infusion of $0.125 \mathrm{\mu g} / \mathrm{kg} / \mathrm{min}$ for 12 hours and postprocedural infusion without heparin.

REMEDIA [41] Heparin (initial weight-adjusted IV bolus then further boluses administered with the aim of obtaining an activated clotting time of 250 to $300 \mathrm{~s}$ in patients treated with abciximab and $>300 \mathrm{~s}$ in the remaining subjects) and with double antiplatelet therapy with aspirin and clopidogrel (loading dose of $300 \mathrm{mg}$ followed by $75 \mathrm{mg} /$ day) for at least four weeks. Unless contraindicated, abciximab $(0.25 \mathrm{mg} / \mathrm{kg}$ bolus plus infusion of $0.125 \mathrm{\mu g} / \mathrm{kg} / \mathrm{min}$ for $12 \mathrm{~h}$ ) was intravenously administered in all patients undergoing primary $\mathrm{PCl}$, whereas in those with failed thrombolysis, abciximab use was left to the operator's discretion.

Shehata 2014 [25] Aspirin (a loading dose of $500 \mathrm{mg}$ ), heparin (70 IU/ $\mathrm{kg}$ ), and clopidogrel (a loading dose of $600 \mathrm{mg}$ ). All patients also received the glycoprotein Ilb/lla inhibitor abciximab with an intravenous procedural bolus of $0.25 \mathrm{mg} / \mathrm{kg}$ followed by a continuous intravenous infusion of $0.125 \mathrm{~g} / \mathrm{kg} / \mathrm{min}$ for 12 hours and postprocedural infusion without heparin.

Sim 2013 [42] Aspirin 300 mg, clopidogrel 600 mg, intravenous unfractionated heparin and nitroglycerin. Oral atenolol 50-100 mg was given to optimize heart rate $\leq 65$ beats per minute prior to $C T$ scan, unless contraindicated.

TAPAS $[43,44] \quad$ Aspirin (a loading dose of $500 \mathrm{mg}$ ), heparin (5000 IU), and clopidogrel (a loading dose of $600 \mathrm{mg}$ ). Patients also received the glycoprotein IIb/llla inhibitor abciximab, with the dose based on body weight, unless contra-indicated, and additional heparin, with the dose based on the activated clotting time.

TASTE $[26,27] \quad$ Patients received the following procedure-related medication: bivalirudin, clopidogrel or ticlopidine, acetylsalicylic acid, ticagrelor, prasugrel, heparin, low-molecular-weight heparin, and glycoprotein llb/llla blocker. The use of platelet inhibitors or anticoagulants was left to the discretion of the treating physician.

TOTAL [6] Unfractionated heparin; bivalirudin; enoxaparin and; glycoprotein Illb/lla inhibitor.

TROFI $[45,46] \quad$ Heparin in ambulance

VAMPIRE [47] Aspirin and intravenous heparin boluses were administered during the procedure to maintain an activated clotting time $\geq 300 \mathrm{~s}$.

Yin 2011 [48] Aspirin $300 \mathrm{mg}$ and clopidogrel $300 \mathrm{mg}$ prior to angiography. 
Twelve studies $[25,28-30,34,35,38-44]$ used aspirin and clopidogrel as a preprocedure antithrombotic therapy; some of them [6, 25-30, 32-35, 38, 39, 41-47] also used intravenous heparin; seven of them had all patients were treated with abciximab [25, 31, $35,39,40,41,43,44]$ and; one of them [42] also used nitroglycerin (Table 2).

The choice of medication during the procedure such as aspirin, heparin, clopidogrel, and glycoprotein IIb/IIIa inhibitors was at the investigator's discretion in one of the included studies [34]. The patients in one further trial $[26,27]$ received the following procedure-related medication: bivalirudin, clopidogrel or ticlopidine, acetylsalicylic acid, ticagrelor, prasugrel, heparin, low-molecular-weight heparin, and glycoprotein IIb/IIIa blocker, while in other one [6] patients received unfractionated heparin; bivalirudin; enoxaparin and; glycoprotein IIb/IIa inhibitor (Table 2). Patients in TROFI trial $[45,46]$ received only heparin in ambulance and, in VAMPIRE trial [47] aspirin and intravenous heparin boluses were administered during the procedure to maintain an activated clotting time $\geq$ $300 \mathrm{~s}$.

\section{Risk of bias assessment}

A possibly important limitation with respect to risk of bias was lack of blinding for caregivers. A number of studies, including the larger ones, blinded the adjudicators of outcome. Follow-up was largely satisfactory: 14 trials lost less than $10 \%$ of patients to follow-up (Table 3 and Fig. 2).

Table 3 Risk of bias assessment

\begin{tabular}{|c|c|c|c|c|c|c|c|c|c|}
\hline Author, year & $\begin{array}{l}\text { Randomization } \\
\text { sequence } \\
\text { adequately } \\
\text { generated? }\end{array}$ & $\begin{array}{l}\text { Allocation } \\
\text { adequately } \\
\text { concealed? }\end{array}$ & $\begin{array}{l}\text { Blinding of } \\
\text { patients and } \\
\text { caregivers? }\end{array}$ & $\begin{array}{l}\text { Blinding } \\
\text { of data } \\
\text { collectors? }\end{array}$ & $\begin{array}{l}\text { Blinding of } \\
\text { adjudicators } \\
\text { of outcome? }\end{array}$ & $\begin{array}{l}\text { Blinding of } \\
\text { data } \\
\text { analysts? }\end{array}$ & $\begin{array}{l}\text { Infrequent } \\
\text { missing } \\
\text { outcome } \\
\text { data? }^{\mathrm{a}}\end{array}$ & $\begin{array}{l}\text { Free of } \\
\text { suggestion } \\
\text { of selective } \\
\text { outcome } \\
\text { reporting? }\end{array}$ & $\begin{array}{l}\text { Free of other } \\
\text { problems that } \\
\text { could put it at } \\
\text { a risk of bias? }\end{array}$ \\
\hline ADMIT (28) & Yes & Yes & No & Probably no & Probably yes & Probably no & Yes & Yes & Yes \\
\hline Bulum 2012 (29) & Probably no & Probably no & No & No & No & No & Yes & Yes & Yes \\
\hline Chao 2008 (30) & Probably yes & Probably no & No & No & No & No & Yes & $\begin{array}{l}\text { Probably } \\
\text { yes }\end{array}$ & Yes \\
\hline De Luca 2006 (31) & Probably no & Probably no & No & Probably no & Probably no & Probably no & No & Yes & Yes \\
\hline EXPIRA $(32,33)$ & Probably yes & Probably no & No & No & Yes & No & $\begin{array}{l}\text { Probably } \\
\text { yes }\end{array}$ & $\begin{array}{l}\text { Probably } \\
\text { yes }\end{array}$ & Probably yes \\
\hline EXPORT (34) & Yes & Yes & No & No & Yes & No & Yes & $\begin{array}{l}\text { Probably } \\
\text { no }\end{array}$ & Probably yes \\
\hline IMPACT (35) & Probably no & Probably no & No & Probably no & Probably no & Probably no & No & No & Yes \\
\hline INFUSE-AMI $(36,37)$ & Yes & Probably no & No & Probably no & Yes & Probably no & Yes & Yes & No \\
\hline ITTI (38) & Yes & Probably no & No & Probably no & Probably yes & Probably no & Yes & Yes & Yes \\
\hline Kaltoft 2006 (39) & Yes & Yes & No & Probably no & Probably no & Probably no & Yes & Yes & Yes \\
\hline Liistro 2009 (40) & Yes & Probably no & No & No & Probably yes & No & $\begin{array}{l}\text { Probably } \\
\text { yes }\end{array}$ & Yes & Yes \\
\hline REMEDIA (41) & Yes & Probably yes & No & No & No & No & $\begin{array}{l}\text { Probably } \\
\text { yes }\end{array}$ & Yes & Probably yes \\
\hline Shehata 2014 (25) & Yes & Yes & No & Probably no & Yes & Probably no & Yes & Yes & Yes \\
\hline Sim 2013 (42) & Probably no & Probably no & No & No & No & No & Yes & $\begin{array}{l}\text { Probably } \\
\text { no }\end{array}$ & Yes \\
\hline TAPAS $(43,44)$ & Yes & Probably yes & No & No & Yes & No & Yes & Yes & Yes \\
\hline TASTE $(26,27)$ & Yes & Yes & No & No & No & Probably no & Yes & Yes & Yes \\
\hline TOTAL (6) & Yes & Yes & No & Probably no & Yes & Probably yes & Yes & Yes & Probably no \\
\hline TROFI $(45,46)$ & Yes & Yes & No & No & Yes & Probably no & Yes & Yes & Yes \\
\hline VAMPIRE (47) & Probably yes & $\begin{array}{l}\text { Probably } \\
\text { no }\end{array}$ & No & No & Yes & No & No & Yes & Probably yes \\
\hline Yin 2011 (48) & No & No & No & No & No & No & No & No & Probably no \\
\hline
\end{tabular}

${ }^{a}$ Defined as less than $10 \%$ loss to outcome data or difference between groups less than $5 \%$ and those excluded are not likely to have made a material difference in the effect observed

All answers as: yes (low risk of bias), probably yes, probably no, no (high risk of bias) 


\section{Outcomes}

Appendix Table 2 presents the mortality data by individual study and Appendix Table 3 presents individual study outcome data for recurrent MI, stroke, and bleeding.

\section{Overall mortality}

In 20 trials [6, 25-48] that addressed overall mortality, 457 of $10,433(4.4 \%)$ patients died in the control arm compared to 403 of $10,433(3.9 \%)$ in the aspiration PCI arm (relative risk (RR) 0.89, $95 \%$ CI 0.78 to $1.01 ; \mathrm{I}^{2}=0 \%$; risk difference (RD) 4/1,000 over 6 months; moderate certainty) (Fig. 3). Certainty in evidence was rated down to moderate because of imprecision and unblinding of caregivers in all included studies (Table 4).

\section{Recurrent myocardial infarction}

In 17 trials [6, 25-29, 31-34, 36-41, 43-48], 246 of $10,331(2.4 \%)$ patients suffered a recurrent MI in the control arm compared to 229 of 10,331 (2.2\%) in the aspiration PCI arm (RR 0.94, $95 \%$ CI 0.79 to 1.12; $\mathrm{I}^{2}=0 \%$; RD $1 / 1,000$ over 6 months; moderate certainty) (Fig. 4). Certainty in evidence was rated down to moderate because of imprecision, lack of blinding of caregivers in all included studies and inadequate or unreported blinding of outcome adjudicators in some studies [26, 27, 29, 31, 39, 41, 48] (Table 4).

\section{Stroke}

In 8 trials [6, 26, 27, 29, 36-39, 41, 45, 46], 77 of 9,185 (0.8\%) patients that underwent aspiration PCI use had a stroke compared to 48 of $9,162(0.5 \%)$ in the PCI alone (RR 1.56, 1.09 to 2.24; $\mathrm{I}^{2}=0 \%$; RD 3/1,000 over 6 months; moderate certainty) (Fig. 5). Certainty in evidence was rated down to moderate because of imprecision, lack of blinding of caregivers in all included studies and inadequate or unreported blinding of outcome adjudicators in some studies [26, 27, 29, 39, 41] (Table 4). We intended to evaluate non-fatal stroke, but data was not available in sufficient number of studies to provide a useful comparison.

\section{Major bleeding}

In 4 trials $[6,36-38,43,44], 99$ of 5823 (1.7\%) patients presented major bleeding in the control arm compared to 101 of $5,832(1.7 \%)$ in the aspiration PCI arm (RR 1.02, 0.78 to $1.35 ; \mathrm{I}^{2}=0 \%$; RD $0 / 1,000$ over 6 months; moderate certainty) (Fig. 6). Certainty in evidence was rated down to moderate because of imprecision and lack of blinding of caregivers in all included studies (Table 4).

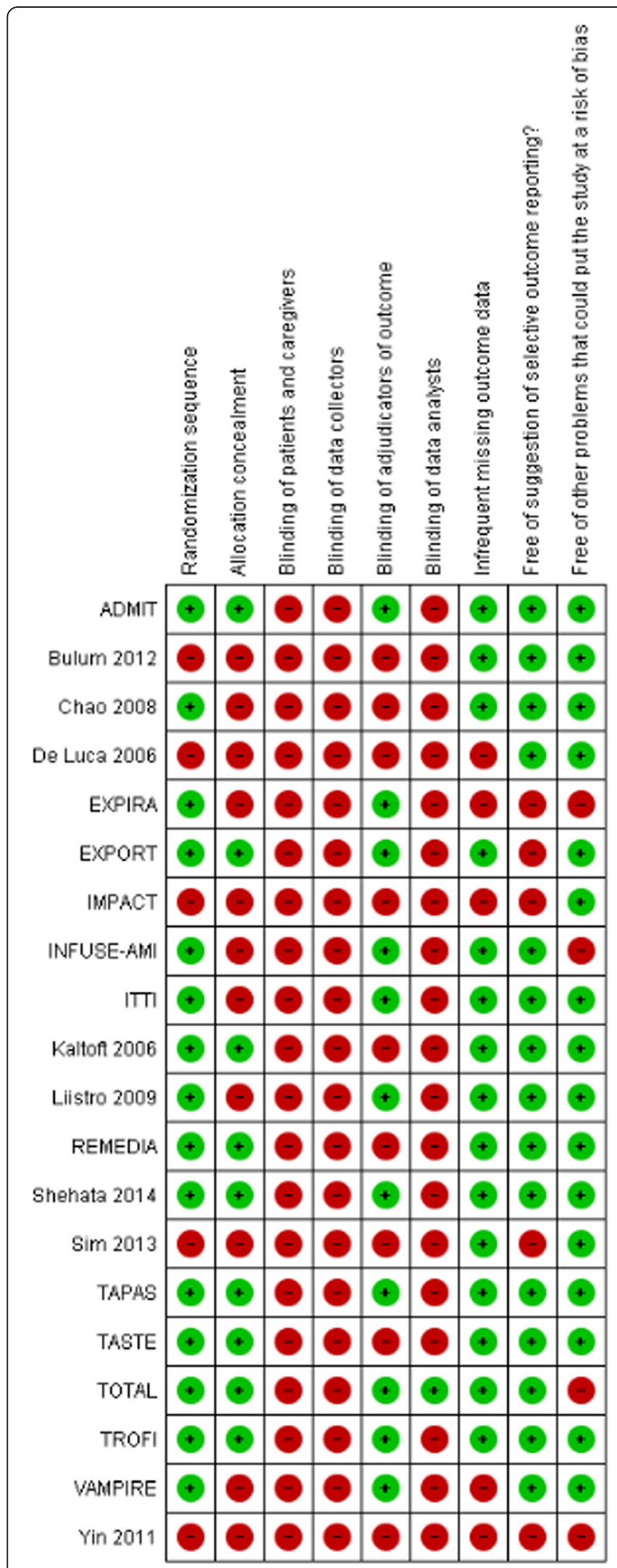

Fig. 2 Risk of bias assessment 


\begin{tabular}{|c|c|c|c|c|c|c|c|c|c|c|}
\hline Study or Subgroup & \multicolumn{2}{|c|}{ Aspiration $\mathrm{PCl}$} & \multicolumn{2}{|c|}{ Conventional PCI } & Weight & \multirow{2}{*}{$\begin{array}{c}\begin{array}{c}\text { Risk Ratio } \\
\text { M-H, Random, } 95 \% \mathrm{CI}\end{array} \\
2.10[0.41,10.84]\end{array}$} & \multicolumn{4}{|c|}{$\begin{array}{c}\text { Risk Ratio } \\
\text { M-H, Random, } 95 \% \mathrm{Cl}\end{array}$} \\
\hline ADMIT & 4 & 41 & 2 & 43 & $0.6 \%$ & & & & & \\
\hline Bulum 2012 & 0 & 30 & 0 & 30 & & Not estimable & & & & \\
\hline Chao 2008 & 1 & 37 & 0 & 37 & $0.2 \%$ & $3.00[0.13,71.34]$ & & & & \\
\hline De Luca 2006 & 0 & 35 & 2 & 38 & $0.2 \%$ & $0.22[0.01,4.36]$ & & & & \\
\hline EXPIRA & 0 & 88 & 4 & 87 & $0.2 \%$ & $0.11[0.01,2.01]$ & & & & \\
\hline EXPORT & 3 & 120 & 5 & 129 & $0.9 \%$ & $0.65[0.16,2.64]$ & & & & \\
\hline IMPACT & 1 & 20 & 1 & 21 & $0.2 \%$ & $1.05[0.07,15.68]$ & & & & \\
\hline INFUSE-AMI & 11 & 222 & 15 & 207 & $3.0 \%$ & $0.68[0.32,1.45]$ & & & - & \\
\hline ITTI & 1 & 52 & 0 & 48 & $0.2 \%$ & $2.77[0.12,66.49]$ & & & & \\
\hline Kaltoft 2006 & 0 & 108 & 1 & 107 & $0.2 \%$ & $0.33[0.01,8.02]$ & & & & \\
\hline Liistro 2009 & 1 & 55 & 0 & 56 & $0.2 \%$ & $3.05[0.13,73.38]$ & & & & \\
\hline REMEDIA & 3 & 48 & 3 & 48 & $0.7 \%$ & $1.00[0.21,4.71]$ & & & & \\
\hline Shehata 2014 & 0 & 48 & 1 & 46 & $0.2 \%$ & $0.32[0.01,7.65]$ & & & & \\
\hline $\operatorname{sim} 2013$ & 1 & 43 & 0 & 43 & $0.2 \%$ & $3.00[0.13,71.65]$ & & & & \\
\hline TAPAS & 25 & 530 & 41 & 530 & $7.4 \%$ & $0.61[0.38,0.99]$ & & -1 & & \\
\hline TASTE & 191 & 3621 & 202 & 3623 & $46.5 \%$ & $0.95[0.78,1.15]$ & & $\Rightarrow$ & & \\
\hline TOTAL & 157 & 5033 & 174 & 5030 & $38.2 \%$ & $0.90[0.73,1.11]$ & & -5 & & \\
\hline TROFI & 0 & 59 & 1 & 61 & $0.2 \%$ & $0.34[0.01,8.29]$ & & & & \\
\hline VAMPIRE & 2 & 170 & 1 & 158 & $0.3 \%$ & $1.86[0.17,20.30]$ & & & & \\
\hline Yin 2011 & 2 & 73 & 4 & 91 & $0.6 \%$ & $0.62[0.12,3.31]$ & & & & \\
\hline Total $(95 \% \mathrm{Cl})$ & & 10433 & & 10433 & $100.0 \%$ & $0.89[0.78,1.01]$ & & 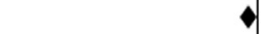 & & \\
\hline \multirow{2}{*}{\multicolumn{7}{|c|}{$\begin{array}{l}\text { Total events } \quad 403 \quad 457 \\
\text { Heterogeneity. Tau }{ }^{2}=0.00 ; \mathrm{Chi}^{2}=11.21 \text {, df }=18(P=0.89) ;\left.\right|^{2}=0 \% \\
\text { Test for overall effect: } Z=1.78(P=0.08)\end{array}$}} & & & & \\
\hline & & & & & & & 0.01 & $\begin{array}{c}0.1 \\
\text { Favours Aspiration } \mathrm{PCI}\end{array}$ & $\begin{array}{c}10 \\
\text { Favours Conventional PCl }\end{array}$ & $\overrightarrow{100}$ \\
\hline
\end{tabular}

More than 10 studies addressed overall mortality and recurrent MI; for both, funnel plots did not suggest publication bias (Appendix: Figures 1 and 2).

\section{Meta-Regression analysis}

Data from studies assessed in a meta-regression showed that the relationship between mortality rates decreased with increasing mean age; however was not significant (slope: $-0.011 ; 95 \%$ confidence interval: -.0980 to $.0765 ; \mathrm{P}=0.784$; Fig. 7 ). Similarly, the relationship between recurrent myocardial infarction rates decreased with increasing mean age; however was not significant (slope: $-0.011 ; 95 \%$ confidence interval: -.1175 to .0944; $\mathrm{P}=0.811$; Fig. 8).

\section{Discussion}

\section{Main findings}

Based on pooled data from 20 randomized trials with more than 20,000 patients, we found moderate quality evidence for a non-statistically significant reduction in overall mortality (4 fewer deaths/1000 treated over 6 months) (Table 4) and a small potential increase in stroke (3 additional strokes/1000 treated over 6 months) (Table 4) in patients treated with thrombectomy. Moderate quality evidence suggests no impact of thrombectomy on either recurrent MI or major bleeding (Table 4).

A number of factors decreased our certainty in the estimates for overall mortality. In particular, the confidence interval included both no reduction in deaths and a mortality reduction that although small (8 fewer deaths in 1,000 over six months), many would consider important. Similarly with stroke: the confidence interval includes no increase in stroke and an increase of 6 more strokes in 1,000 patients over 6 months with thrombectomy, which many would consider an important risk. Other issues decreasing confidence in our estimates included potential risk of bias imposed by lack of blinding of patients and health care providers in all studies, and lack of blinding of outcome adjudicators in some studies.

The meta-regression analyses showed that both mortality and recurrent myocardial infarction rates decreased with increasing mean age. However, there was a non-significant difference between these two variables and the mean age of participants in both studied groups. A study [49] evaluated through a meta-regression whether there is an association between age, gender, diabetes mellitus, previous myocardial infarction and ejection fraction, and the choice of revascularization, focusing on death, myocardial infarction, repeat revascularization and stroke. The authors found that the reduction in stroke was significantly higher in females, and that women and patients with diabetes mellitus were at increased risk of subsequent revascularization after PCI [49].

\section{Strengths and limitations}

Strengths of our review include a comprehensive search; assessment of eligibility, risk of bias, and data abstraction independently and in duplicate; use of the GRADE 
Table 4 GRADE evidence profile: Aspiration thrombectomy (AT) prior to PCl in patients with STEMI

\begin{tabular}{|c|c|c|c|c|c|c|c|c|c|c|c|}
\hline \multicolumn{6}{|l|}{ Quality assessment } & \multicolumn{5}{|c|}{ Summary of findings } & \multirow{3}{*}{$\begin{array}{l}\text { Certainty in estimates } \\
\text { OR Quality of evidence }\end{array}$} \\
\hline \multirow[b]{2}{*}{$\begin{array}{l}\text { No of participants(studies) } \\
\text { Range follow-up time }\end{array}$} & \multirow[b]{2}{*}{ Risk of bias } & \multirow[b]{2}{*}{ Inconsistency } & \multirow[b]{2}{*}{ Indirectness } & \multirow[b]{2}{*}{ Imprecision } & \multirow[b]{2}{*}{ Publication bias } & \multicolumn{2}{|c|}{ Study event rates } & \multirow[t]{2}{*}{$\begin{array}{l}\text { Relative risk } \\
(95 \% \mathrm{Cl})\end{array}$} & \multicolumn{2}{|c|}{$\begin{array}{l}\text { Anticipated absolute effects over6 } \\
\text { months }\end{array}$} & \\
\hline & & & & & & Without AT & With AT & & Without AT & With AT & \\
\hline \multicolumn{12}{|c|}{ Overall mortality (Includes cardiovascular (CV) mortality for studies only reporting CV mortality) } \\
\hline 20866 (20) 6-12 mo & $\begin{array}{l}\text { No serious } \\
\text { limitations }^{1}\end{array}$ & $\begin{array}{l}\text { No serious } \\
\text { limitations }\end{array}$ & $\begin{array}{l}\text { No serious } \\
\text { limitations }^{2}\end{array}$ & $\begin{array}{l}\text { Serious } \\
\text { imprecision }^{1,3}\end{array}$ & Undetected & $457 / 10433$ & $403 / 10433$ & 0.89 (0.78-1.01) & 35 per $1000^{4}$ & $\begin{array}{l}4 \text { fewer per } 1000 \\
\text { (8 fewer to } 0 \text { more) }\end{array}$ & $\begin{array}{l}\oplus \oplus \oplus \oplus \mathrm{O} \text { MODERATE, } \\
\text { due to imprecision }\end{array}$ \\
\hline \multicolumn{12}{|l|}{$\begin{array}{l}\text { Recurrent myocardial } \\
\text { infarction }\end{array}$} \\
\hline 20662 (17) 6-12 mo & $\begin{array}{l}\text { No serious } \\
\text { limitations }{ }^{1}\end{array}$ & $\begin{array}{l}\text { No serious } \\
\text { limitations }\end{array}$ & $\begin{array}{l}\text { No serious } \\
\text { limitations }\end{array}$ & $\begin{array}{l}\text { Serious } \\
\text { imprecision }\end{array}$ & Undetected & $\begin{array}{l}246 / 10331 \\
(2.3 \%)\end{array}$ & $\begin{array}{l}229 / 10331 \\
(2.2 \%)\end{array}$ & $0.94(0.79-1.12)$ & 18 per $1000^{4}$ & $\begin{array}{l}1 \text { fewer per } 1000 \\
(4 \text { fewer to } 2 \text { more) }\end{array}$ & $\begin{array}{l}\oplus \oplus \oplus \oplus \mathrm{O} \text { MODERATE, } \\
\text { due to imprecision }\end{array}$ \\
\hline \multicolumn{12}{|l|}{ Stroke } \\
\hline 18348 (8) 6-12 mo & $\begin{array}{l}\text { No serious } \\
\text { limitations }{ }^{1}\end{array}$ & $\begin{array}{l}\text { No serious } \\
\text { limitations }\end{array}$ & $\begin{array}{l}\text { No serious } \\
\text { limitations }\end{array}$ & $\begin{array}{l}\text { Serious } \\
\text { imprecision } 1,6\end{array}$ & Undetected & $\begin{array}{l}48 / 9163 \\
(0.5 \%)\end{array}$ & $\begin{array}{l}77 / 9185 \\
(0.8 \%)\end{array}$ & $1.56(1.09-2.24)$ & 5 per $1000^{4}$ & $\begin{array}{l}3 \text { more per } 1000 \\
(0 \text { more to } 6 \text { more) }\end{array}$ & $\begin{array}{l}\oplus \oplus \oplus \oplus \mathrm{O} \text { MODERATE, } \\
\text { due to imprecision }\end{array}$ \\
\hline \multicolumn{12}{|l|}{ Major bleeding } \\
\hline 11655 (4) 6-12 mo & $\begin{array}{l}\text { No serious } \\
\text { limitations }^{1}\end{array}$ & $\begin{array}{l}\text { No serious } \\
\text { limitations }\end{array}$ & $\begin{array}{l}\text { No serious } \\
\text { limitations }\end{array}$ & $\begin{array}{l}\text { Serious } \\
\text { imprecision }^{1,5}\end{array}$ & Undetected & $\begin{array}{l}99 / 5823 \\
(1.7 \%)\end{array}$ & $\begin{array}{l}101 / 5832 \\
(1.7 \%)\end{array}$ & $1.02(0.78-1.35)$ & 15 per $1000^{4}$ & $\begin{array}{l}0 \text { more per } 1000 \\
\text { (3 fewer to } 5 \text { more) }\end{array}$ & $\begin{array}{l}\oplus \oplus \oplus \oplus \mathrm{O} \text { MODERATE, } \\
\text { due to imprecision }\end{array}$ \\
\hline
\end{tabular}

${ }^{1}$ No studies were blinded to patient or caregiver. Some studies (minority of subjects enrolled) did not indicate blinded adjudication. While not specifically rating down for risk of bias, these additional concerns plus borderline clinically important imprecision led to downgrading of certainty in estimates for all outcomes

${ }^{2}$ Some studies only report cardiovascular and not all cause mortality. However cardiovascular mortality constituted significant proportion of overall mortality in studies reporting both types of mortality. Therefore we opted against rating down for indirectness

${ }_{3}^{3} 95 \%$ Cl for absolute effects include clinically important benefit and no benefit

${ }^{4}$ Baseline risk estimates for mortality, recurrent MI, stroke, and major bleeds come from control arm of TOTAL study (largest and most recent randomized trial)

${ }_{95 \%} \mathrm{Cl}$ for absolute effects include benefit and harm

${ }^{6} 95 \% \mathrm{Cl}$ for absolute effects include clinically important harm and no harm 


\begin{tabular}{|c|c|c|c|c|c|c|c|c|c|c|}
\hline Study or Subgroup & \multicolumn{2}{|c|}{ Aspiration $\mathrm{PCI}$} & \multicolumn{2}{|c|}{ Conventional PCI } & Weight & \multirow{2}{*}{$\begin{array}{c}\begin{array}{c}\text { Risk Ratio } \\
\text { M-H, Random, 95\% CI }\end{array} \\
1.08[0.23,5.02]\end{array}$} & \multicolumn{4}{|c|}{$\begin{array}{c}\text { Risk Ratio } \\
\text { M-H, Random, } 95 \% \mathrm{CI}\end{array}$} \\
\hline ADMIT & 3 & 39 & 3 & 42 & $1.3 \%$ & & & & & \\
\hline Bulum 2012 & 0 & 30 & 0 & 30 & & Not estimable & & & & \\
\hline De Luca 2006 & 1 & 35 & 0 & 38 & $0.3 \%$ & $3.25[0.14,77.25]$ & & & & \\
\hline EXPIRA & 0 & 88 & 1 & 87 & $0.3 \%$ & $0.33[0.01,7.98]$ & & & & \\
\hline EXPORT & 2 & 120 & 1 & 129 & $0.6 \%$ & $2.15[0.20,23.41]$ & & & & \\
\hline INFUSE-AMI & 1 & 222 & 3 & 207 & $0.6 \%$ & $0.31[0.03,2.96]$ & & & & \\
\hline ITTI & 2 & 52 & 5 & 48 & $1.3 \%$ & $0.37[0.08,1.81]$ & & & E & \\
\hline Kaltoft 2006 & 0 & 108 & 1 & 107 & $0.3 \%$ & $0.33[0.01,8.02]$ & & & & \\
\hline Liistro 2009 & 3 & 55 & 3 & 56 & $1.3 \%$ & $1.02[0.21,4.83]$ & & & & \\
\hline REMEDIA & 2 & 48 & 2 & 48 & $0.9 \%$ & $1.00[0.15,6.81]$ & & & & \\
\hline Shehata 2014 & 4 & 48 & 6 & 46 & $2.2 \%$ & $0.64[0.19,2.12]$ & & & - & \\
\hline TAPAS & 12 & 530 & 23 & 530 & $6.7 \%$ & $0.52[0.26,1.04]$ & & & & \\
\hline TASTE & 96 & 3621 & 99 & 3623 & $41.5 \%$ & $0.97[0.74,1.28]$ & & $\rightarrow$ & - & \\
\hline TOTAL & 99 & 5033 & 92 & 5030 & $40.3 \%$ & $1.08[0.81,1.42]$ & & & - & \\
\hline TROFI & 1 & 59 & 0 & 61 & $0.3 \%$ & $3.10[0.13,74.61]$ & & & & \\
\hline VAMPIRE & 0 & 170 & 1 & 158 & $0.3 \%$ & $0.31[0.01,7.55]$ & & & & \\
\hline Yin 2011 & 3 & 73 & 6 & 91 & $1.7 \%$ & $0.62[0.16,2.41]$ & & & - & \\
\hline Total $(95 \% \mathrm{Cl})$ & & 10331 & & 10331 & $100.0 \%$ & $0.94[0.79,1.12]$ & & & & \\
\hline Total events & 229 & & 246 & & & & & & & \\
\hline $\begin{array}{l}\text { Heterogeneity. } \mathrm{Tau}^{2}= \\
\text { Test for overall effect: }\end{array}$ & $\begin{array}{l}0.00 ; \mathrm{Chi}^{2} \\
\mathrm{z}=0.69\end{array}$ & $\begin{array}{l}=9.68 \\
P=0.49\end{array}$ & df $=15(P$ & $=0.84 \mathrm{l}$ & $\left.\right|^{2}=0 \%$ & & 0.01 & $\begin{array}{c}0.1 \\
\text { Favours Aspiration } \mathrm{PCl}\end{array}$ & $\begin{array}{c}10 \\
\text { Favours Conventional PCI }\end{array}$ & $\overrightarrow{100}$ \\
\hline
\end{tabular}

approach in rating the quality of evidence for each outcome; and focus on absolute as well as relative effects of the intervention on patient-important outcomes. In this case, the small and more or less equivalent number of possible deaths prevented and strokes caused by thrombectomy, and the uncertainty consequent on the imprecision and risk of bias issues, are crucial in considering patient management (Table 4).

Potential limitations are related to the available data. Trials often suffered from incomplete outcome reporting, and lack of blinding consequent on the nature of the intervention, but for some studies also avoidable lack of blinding (outcome adjudication).

\section{Relation to prior work}

Recently published results from another metaanalysis [50] as well as data from a limited metaanalysis conducted as part of an evaluation of the outcome of stroke in the TOTAL study [12] are in general consistent with our findings. Results from all three analyses are in general consistent with our findings. Our systematic review and meta-analysis nevertheless adds important information as a result of our comprehensive assessment of risk of bias issues, our use of a complete case analysis that avoids assumptions regarding patients lost to follow-up, our use of the GRADE approach to rate quality of evidence, and our focus on absolute effects of thrombectomy required for optimal decisionmaking.

Furthermore, another review compared the effects of thrombectomy as an adjunct to PCI in the management of acute myocardial infarction in 20,853 patients [51]. The authors concluded that mortality; reinfarction and; stent thrombosis rates did not differ significantly between patients treated with or without AT; but stroke rates were increased with AT [51].

\begin{tabular}{|c|c|c|c|c|c|c|c|c|c|c|}
\hline Study or Subgroup & $\begin{array}{l}\text { Aspiratic } \\
\text { Events }\end{array}$ & $\begin{array}{l}\text { n PCI } \\
\text { Total } \\
\end{array}$ & $\begin{array}{c}\text { Conventio } \\
\text { Events }\end{array}$ & $\begin{array}{l}\text { al PCI } \\
\text { Total } \\
\end{array}$ & Weight & $\begin{array}{c}\text { Risk Ratio } \\
\text { M-H, Random, } 95 \% \mathrm{Cl} \\
\end{array}$ & \multicolumn{4}{|c|}{$\begin{array}{c}\text { Risk Ratio } \\
\text { M-H, Random, } 95 \% \mathrm{CI}\end{array}$} \\
\hline Bulum 2012 & 0 & 30 & 0 & 30 & & Not estimable & & & & \\
\hline INFUSE-AMI & 2 & 222 & 3 & 207 & $4.2 \%$ & $0.62[0.10,3.68]$ & & & & \\
\hline ITTI & 1 & 52 & 0 & 48 & $1.3 \%$ & $2.77[0.12,66.49]$ & & & & \\
\hline Kaltoft 2006 & 2 & 108 & 0 & 107 & $1.4 \%$ & $4.95[0.24,101.99]$ & & & & \\
\hline REMEDIA & 1 & 48 & 1 & 48 & $1.7 \%$ & $1.00[0.06,15.53]$ & & & & \\
\hline TASTE & 19 & 3621 & 18 & 3623 & $31.8 \%$ & $1.06[0.56,2.01]$ & & & & \\
\hline TOTAL & 52 & 5033 & 25 & 5030 & $58.2 \%$ & $2.08[1.29,3.34]$ & & & 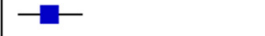 & \\
\hline TROFI & 0 & 71 & 1 & 70 & $1.3 \%$ & $0.33[0.01,7.93]$ & & & & \\
\hline Total $(95 \% \mathrm{CI})$ & & 9185 & & 9163 & $100.0 \%$ & $1.56[1.09,2.24]$ & & & & \\
\hline Total events & 77 & & 48 & & & & & & & \\
\hline $\begin{array}{l}\text { Heterogeneity. } \mathrm{Tau}^{2}= \\
\text { Test for overall effect: }\end{array}$ & $\begin{array}{l}0.00 ; \mathrm{Chi} \\
z=2.41\end{array}$ & $\begin{array}{l}=5.55 \\
P=0.02\end{array}$ & df $=6(P$ & $0.48 \mathrm{~J} ; \mathrm{I}^{2}$ & $=0 \%$ & & 0.01 & $\begin{array}{c}0.1 \\
\text { Favours Aspiration } \mathrm{PCl}\end{array}$ & $\begin{array}{c}10 \\
\text { Favours Conventional PCI }\end{array}$ & 100 \\
\hline
\end{tabular}




\begin{tabular}{|c|c|c|c|c|c|c|c|c|c|c|}
\hline Study or Subgroup & $\begin{array}{l}\text { Aspiratio } \\
\text { Events }\end{array}$ & $\begin{array}{l}\text { n PCI } \\
\text { Total }\end{array}$ & $\begin{array}{c}\text { Conventio } \\
\text { Events }\end{array}$ & $\begin{array}{l}\text { al PCI } \\
\text { Total }\end{array}$ & Weight & $\begin{array}{c}\text { Risk Ratio } \\
\text { M-H, Random, } 95 \% \mathrm{Cl}\end{array}$ & & $\begin{array}{r}\text { Risk } \\
\text { M-H, Rand } \\
\end{array}$ & $\begin{array}{l}\text { Ratio } \\
\text { lom, } 95 \% \mathrm{CI}\end{array}$ & \\
\hline INFUSE-AMI & 2 & 218 & 4 & 214 & $2.7 \%$ & $0.49[0.09,2.65]$ & & & & \\
\hline ITTI & 0 & 52 & 0 & 48 & & Not estimable & & & & \\
\hline TAPAS & 20 & 529 & 18 & 531 & $19.3 \%$ & $1.12[0.60,2.08]$ & & & & \\
\hline TOTAL & 79 & 5033 & 77 & 5030 & $78.0 \%$ & $1.03[0.75,1.40]$ & & & & \\
\hline Total $(95 \% \mathrm{Cl})$ & & 5832 & & 5823 & $100.0 \%$ & $1.02[0.78,1.35]$ & & & & \\
\hline \multirow{2}{*}{\multicolumn{6}{|c|}{$\begin{array}{l}\text { Heterogeneity. } \text { Tau }^{2}=0.00 ; \mathrm{Chi}^{2}=0.80, \mathrm{df}=2(\mathrm{P}=0.67) ; \mathrm{I}^{2}=0 \% \\
\text { Test for overall effect: } Z=0.15(\mathrm{P}=0.88)\end{array}$}} & & & & & \\
\hline & & & & & & & 0.01 & $\begin{array}{c}0.1 \\
\text { Favours Aspiration } \mathrm{PCl}\end{array}$ & 1 Favours Conventional PCl & 100 \\
\hline
\end{tabular}

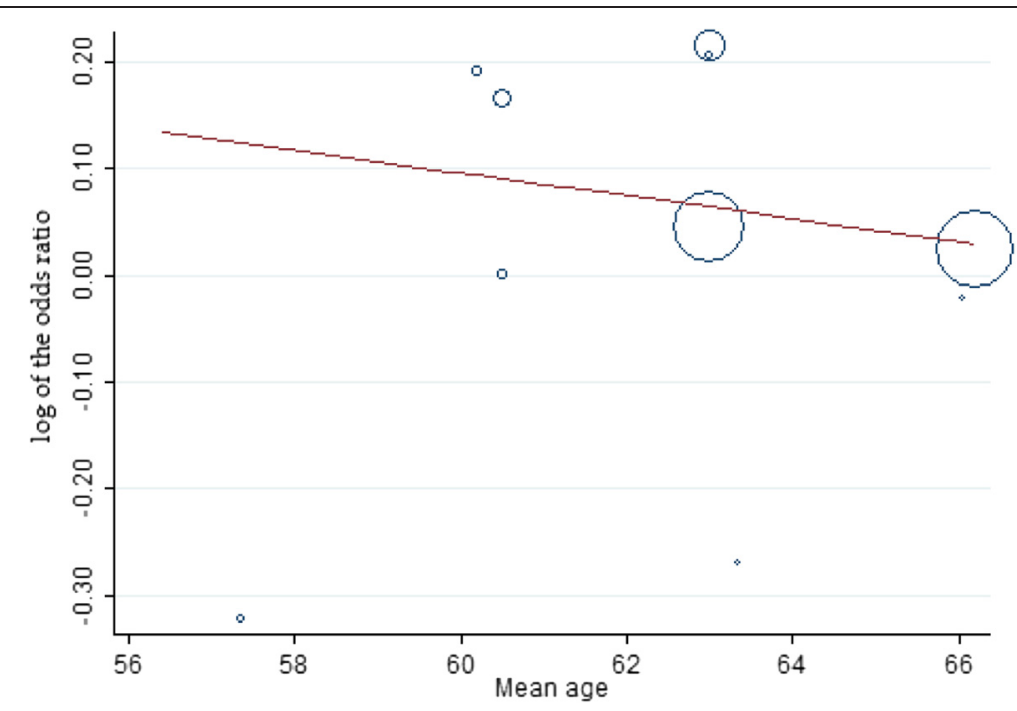

Fig. 7 Meta-regression of mortality rates by mean age. Each circle represents a study highlighted by its weight in the analysis. The relationship between mortality and mean age in both groups was not significant (slope: $-0.011 ; 95 \%$ confidence interval: -.0980 to $.0765 ; P=0.784$ )

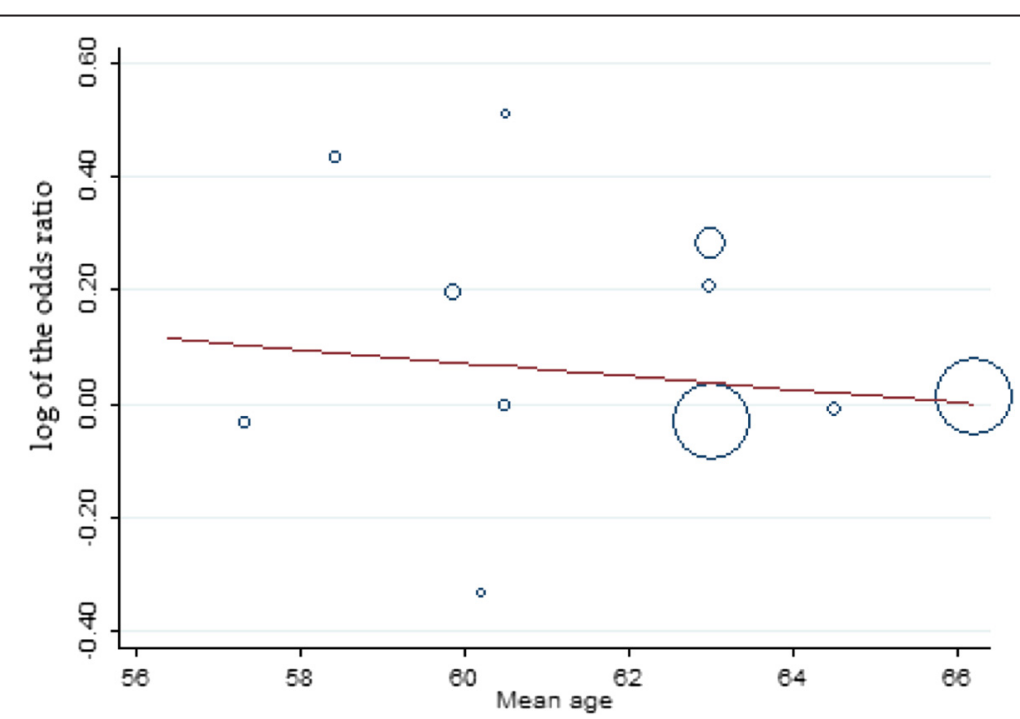

Fig. 8 Meta-regression of recurrent myocardial infarction rates by mean age. Each circle represents a study highlighted by its weight in the analysis. The relationship between recurrent myocardial infarction and mean age in both groups was not significant (slope: $-0.011 ; 95 \%$ confidence interval: -.1175 to $.0944 ; P=0.811$ ) 


\section{Implications}

The possible magnitude of benefit with respect to mortality and magnitude of harm with respect to stroke are small - some might say very small - and similar both with respect to magnitude and likelihood that the effects are real. With respect to mortality, the most likely mechanism of benefit would be a reduction in recurrent MI; the data, however, provide no support for an impact of thrombectomy on MI.

Similarly the mechanism of an increase in stroke is not immediately apparent. In a recent analysis of data from the TOTAL study, thrombectomy was associated with a small increase in procedure time as well as increased use of larger catheters $(99.2 \%$ vs. $97.5 \%>5$ French) [12]. One could postulate this could lead to an increase in embolization of aortic atherosclerotic plaque leading to increased early ischemic events. More frequent development of subsequent atrial fibrillation would constitute another possible mechanism; no study reported this outcome.

Initial enthusiasm for thrombectomy was motivated by evidence of improvement in markers of myocardial tissue reperfusion. Our findings emphasize the need for caution with respect to surrogates, and the desirability of focus on outcomes important to patients. While it is not routinely justified there may be individual cases in which an operator may feel the potential benefit of the procedure outweighs potential risks.

The absolute effects of thrombectomy prior to primary PCI are very small and still associated with uncertainty. Given the best estimates of effect and associated quality of evidence, fully informed risk adverse patients - and particularly those who are highly stroke risk averse - would likely decline thrombectomy. Patients who place high value on an uncertain mortality reduction and have limited concern regarding a possible stroke increase would be more likely to choose to undergo the procedure. Given current concerns regarding overtreatment and efficient use of health care resources, a policy decision to not use thrombectomy in a particular catheterization laboratory is defensible.

\section{Conclusions}

Moderate certainty evidence suggests aspiration thrombectomy is associated with a possible small decrease in mortality (4 less deaths/1000 over 6 months) and a small increase in stroke (3 more strokes/1000 over 6 months). Because absolute effects are very small and closely balanced, thrombectomy prior to primary PCI should not be used as a routine strategy.

\section{Appendix}

Table 5 Search strategy Ovid MEDLINE(R) 1946 to present with daily update

Ovid MEDLINE(R) in-process \& other non-indexed citations June 24, 2015

1. myocardial infarction.ti,ab 194029

2 *Infarction/ 4551

3 Myocardial Infarction/ 145002

4 or/1-3 201604

5 thrombus aspiration.ti,ab. $\quad 400$

6 thromboaspiration.ti,ab. $\quad 125$

7 (aspiration adj5 mechanical).ti,ab. 214

8 Thrombectomy.ti,ab. 4995

9 (aspiration and catheter*).ti,ab. 2140

10 thrombosuction.ti,ab. 34

11 *Thrombectomy/ 2028

12 or/5-11 7869

13 randomized controlled trial.pt. 398533

14 controlled clinical trial.pt. $\quad 89780$

15 randomized.ab. 324620

16 placebo.ab. 163833

17 drug therapy.fs. 1786167

18 randomly.ab. 233298

19 trial.ab. 336144

20 groups.ab. 1465972

21 or/13-20 3564150

22 and $/ 4,12,21 \quad 349$

23 exp animals/ not humans.sh. 4063058

$24 \quad 22$ not 23

Embase 1974 to 2015 June 24

1. Myocardial Infarction.ti,ab. 138908

2 heart infarction/ or acute heart infarction/ or infarction/ 298819 or ST segment elevation myocardial infarction/

3 myocardial disease/ 4499

4 or/1-3 335897

5 thrombus aspiration.ti,ab. 899

6 thromboaspiration.ti,ab. 227

7 (aspiration adj5 mechanical).ti,ab. 328

8 Thrombectomy.ti,ab. 7683

9 (aspiration and catheter*).ti,ab. $\quad 3379$

10 thrombosuction.ti,ab. 59

11 *Thrombectomy/ 1973

12 or/5-11 11913

13 random\$.tw. 995701

14 factorial\$.tw. 25787

15 (crossover\$ or cross-over\$).tw. 
Table 5 Search strategy (Continued)

\begin{tabular}{|c|c|c|}
\hline 16 & placebo\$.tw. & 221322 \\
\hline 17 & (doubl\$ adj blind\$).tw. & 158296 \\
\hline 18 & (singl\$ adj blind\$).tw. & 16231 \\
\hline 19 & assign\$.tw. & 266556 \\
\hline 20 & allocat\$.tw. & 95221 \\
\hline 21 & volunteer\$.tw. & 195251 \\
\hline 22 & Crossover Procedure.sh. & 43314 \\
\hline 23 & Double-blind Procedure.sh. & 123817 \\
\hline 24 & Randomized Controlled Trial.sh. & 377450 \\
\hline 25 & Single-blind Procedure.sh. & 20454 \\
\hline 26 & or/13-25 & 1582267 \\
\hline 27 & animals/ not humans/ & 1258280 \\
\hline 28 & and $/ 4,12,26$ & 454 \\
\hline 29 & 28 not 27 & 454 \\
\hline \multicolumn{3}{|c|}{ CENTRAL Issue 5 of 12, May 2015} \\
\hline$\# 1$ & $\begin{array}{l}\text { myocardial infarction:ti,ab,kw (Word variations have been } \\
\text { searched) }\end{array}$ & 17426 \\
\hline \#2 & MeSH descriptor: [Infarction] explode all trees & 18 \\
\hline \#3 & MeSH descriptor: [Myocardial Infarction] explode all trees & 8885 \\
\hline$\# 4$ & $\# 1$ or \#2 or \#3 & 17525 \\
\hline$\# 5$ & $\begin{array}{l}\text { thrombus aspiration:ti,ab,kw (Word variations have been } \\
\text { searched) }\end{array}$ & 151 \\
\hline \#6 & $\begin{array}{l}\text { thromboaspiration:ti,ab,kw (Word variations have been } \\
\text { searched) }\end{array}$ & 10 \\
\hline \#7 & $\begin{array}{l}\text { aspiration mechanical:ti,ab,kw (Word variations have } \\
\text { been searched) }\end{array}$ & 251 \\
\hline \#8 & $\begin{array}{l}\text { thrombectomy:ti,ab,kw (Word variations have been } \\
\text { searched) }\end{array}$ & 336 \\
\hline$\# 9$ & $\begin{array}{l}\text { aspiration catheter*ti,ab,kw (Word variations have been } \\
\text { searched) }\end{array}$ & 293 \\
\hline$\# 10$ & $\begin{array}{l}\text { thrombosuction:ti,ab,kw (Word variations have been } \\
\text { searched) }\end{array}$ & 4 \\
\hline$\# 11$ & MeSH descriptor: [Thrombectomy] explode all trees & 144 \\
\hline$\# 12$ & $\# 5$ or \#6 or \#7 or \#8 or \#9 or \#10 or \#11 & 860 \\
\hline \multirow[t]{2}{*}{$\# 13$} & $\# 4$ and \#12 & 216 \\
\hline & In Trials & 195 \\
\hline
\end{tabular}

Table 6 Mortality data

\begin{tabular}{|c|c|c|c|c|}
\hline $\begin{array}{l}\text { Acronym } \\
\text { (author, year) }\end{array}$ & $\begin{array}{l}\text { No. included in } \\
\text { analysis } \\
\text { (intervention/ } \\
\text { control) }\end{array}$ & $\begin{array}{l}\text { Follow- } \\
\text { up time } \\
\text { (month)* }\end{array}$ & $\begin{array}{l}\text { Cardiac-specific } \\
\text { mortality } \\
\text { (intervention/ } \\
\text { control) }\end{array}$ & $\begin{array}{l}\text { Overall } \\
\text { mortality } \\
\text { (intervention/ } \\
\text { control) }\end{array}$ \\
\hline \multirow[t]{2}{*}{ ADMIT [28] } & $41 / 43$ & 6 & & $4 / 41 ; 2 / 43$ \\
\hline & $47 / 47$ & 1 & & $3 / 47 ; 1 / 47$ \\
\hline $\begin{array}{l}\text { Bulum } 2012 \\
\text { [29] }\end{array}$ & $30 / 30$ & 6 & & $0 / 30 ; 0 / 30$ \\
\hline $\begin{array}{l}\text { Chao } 2008 \\
\text { [30] }\end{array}$ & $37 / 37$ & 6 & NA & $1 / 37 ; 0 / 37$ \\
\hline $\begin{array}{l}\text { De Luca } 2006 \\
\text { [31] }\end{array}$ & $35 / 38$ & 6 & & $0 / 35 ; 2 / 38$ \\
\hline \multirow[t]{2}{*}{ EXPIRA[32, 33] } & $88 / 87$ & 24 & $0 / 88 ; 6 / 87$ & 0/88; 6/87 \\
\hline & $88 / 87$ & 9 & 0/88; 4/87 & 0/88; 4/87 \\
\hline EXPORT [34] & $120 / 129$ & 1 & $3 / 120 ; 5 / 129$ & $3 / 120 ; 5 / 129$ \\
\hline IMPACT[35] & $20 / 21$ & 6 & $1 / 20 ; 1 / 21$ & $1 / 20 ; 1 / 21$ \\
\hline \multirow[t]{2}{*}{$\begin{array}{l}\text { INFUSE AMI } \\
{[36,37]}\end{array}$} & $222 / 207$ & 12 & NA & $\begin{array}{l}11 / 222 ; 15 / \\
207\end{array}$ \\
\hline & $218 / 214$ & 1 & & $0 / 218 ; 1 / 214$ \\
\hline птा [38] & $52 / 48$ & 6 & & $1 / 52 ; 0 / 48$ \\
\hline $\begin{array}{l}\text { Kaltoft } 2006 \\
\text { [39] }\end{array}$ & $108 / 107$ & 1 & NA & $0 / 108 ; 1 / 107$ \\
\hline $\begin{array}{l}\text { Liistro } 2009 \\
\text { [40] }\end{array}$ & $55 / 56$ & 6 & $1 / 55 ; 0 / 56$ & $1 / 55 ; 0 / 56$ \\
\hline REMEDIA[41] & $48 / 48$ & 1 & NA & $3 / 48 ; 3 / 48$ \\
\hline $\begin{array}{l}\text { Shehata } 2014 \\
\text { [25] }\end{array}$ & $48 / 46$ & 8 & $0 / 48 ; 1 / 46$ & $0 / 48 ; 1 / 46$ \\
\hline Sim 2013 [42] & $43 / 43$ & 12 & NA & $1 / 43 ; 0 / 43$ \\
\hline \multirow[t]{2}{*}{$\operatorname{TAPAS}[43,44]$} & $530 / 530$ & 12 & 19/530; 36/530 & $\begin{array}{l}25 / 530 ; 41 / \\
530\end{array}$ \\
\hline & $529 / 531$ & 1 & NA & $\begin{array}{l}11 / 529 ; 21 / \\
531\end{array}$ \\
\hline \multirow[t]{2}{*}{ TASTE $[26,27]$} & $3621 / 3623$ & 12 & & $\begin{array}{l}\text { 295/3621; } \\
316 / 3623\end{array}$ \\
\hline & $3621 / 3623$ & $1-12$ & & $\begin{array}{l}\text { 191/3621; } \\
\text { 202/3623 }\end{array}$ \\
\hline TOTAL [6] & $5033 / 5030$ & 6 & $\begin{array}{l}\text { 157/5033; 174/ } \\
5030\end{array}$ & $\begin{array}{l}\text { 157/5033; } \\
\text { 174/5030 }\end{array}$ \\
\hline TROFI $[45,46]$ & $59 / 61$ & 12 & $0 / 59 ; 1 / 61$ & $0 / 59 ; 1 / 61$ \\
\hline VAMPIRE [47] & $170 / 158$ & 8 & & 2/170; 1/158 \\
\hline Yin 2011 [48] & 73/91 & 12 & NA & $2 / 73 ; 4 / 91$ \\
\hline
\end{tabular}

*Preference for 6-month mortality, then any defined period closest to 6 months, however abstract in-hospital mortality if that is the only one available was excluded from review 
Table 7 Outcome data per study

\begin{tabular}{|c|c|c|c|c|c|}
\hline Author, year & $\begin{array}{l}\text { No. included in analysis } \\
\text { (intervention/ control) }\end{array}$ & Follow-up time (Month) & $\begin{array}{l}\text { No. (\%) of major bleeding } \\
\text { (intervention/ control) }\end{array}$ & $\begin{array}{l}\text { No. (\%) of non-fatal stroke } \\
\text { (intervention/ control) }\end{array}$ & $\begin{array}{l}\text { No. (\%) of recurrent } \\
\text { myocardial infarction } \\
\text { (intervention/ control) }\end{array}$ \\
\hline \multirow[t]{3}{*}{ ADMIT [28] } & $39 / 42$ & 6 & & & $3(7.7) / 3(7)$ \\
\hline & $42 / 46$ & 1 & & & $2(4.7) / 0$ \\
\hline & $49 / 51$ & 0 & & & $1(2) / 0$ \\
\hline Bulum 2012 [29] & $30 / 30$ & 6 & & $0 / 0$ & $0 / 0$ \\
\hline Chao 2008 [30] & $37 / 37$ & & & & \\
\hline De Luca 2006 [31] & $35 / 38$ & 6 & & & $1 / 0$ \\
\hline EXPIRA $[32,33]$ & $88 / 87$ & 24 & & & 0/1(1.14) \\
\hline EXPORT [34] & $120 / 129$ & 1 & & & $2(0.016) / 1(0.77)$ \\
\hline IMPACT [35] & $20 / 21$ & 6 & & & \\
\hline \multirow[t]{2}{*}{ INFUSE AMI $[36,37]$} & $222 / 207$ & 12 & NA & $2(0.9) / 3(1.4)$ & $1(0.45) / 3(1.4)$ \\
\hline & $218 / 214$ & 1 & $2(0.9) / 4(1.86)$ & $0 / 1(0.46)$ & $1(0.45) / 2(0.93)$ \\
\hline ITTI [38] & $52 / 48$ & 6 & $0 / 0$ & $1(1.92) / 0(0)$ & $2(3.84) / 5(10.41)$ \\
\hline Kaltoft 2006 [39] & 108/107 & 1 & & $2(1.85) / 0(0)$ & 0/1(0.93) \\
\hline Liistro 2009 [40] & $55 / 56$ & & & & $3(5.4) / 3(5.3)$ \\
\hline REMEDIA [41] & $48 / 48$ & 1 & & $1(2) / 1(2)$ & $2(4) / 2(4)$ \\
\hline Shehata 2014 [25] & $48 / 46$ & 8 & & & $4(8) / 6(13)$ \\
\hline $\operatorname{Sim} 2013$ [42] & $43 / 43$ & 12 & & & \\
\hline \multirow[t]{2}{*}{ TAPAS $[43,44]$} & $529 / 531$ & 1 & 20(3.78)/18(3) & & $4(0.75) / 10(1.88)$ \\
\hline & $530 / 530$ & 12 & & & $12(2.26) / 23(4.3)$ \\
\hline \multirow[t]{2}{*}{ TASTE $[26,27]$} & $3621 / 3623$ & 12 & & $19(0.52) / 18(0.4)^{*}$ & $96(2.7) / 99(2.7)$ \\
\hline & $3621 / 3623$ & 1 & & & $19(0.52) / 31(0.85)$ \\
\hline \multirow[t]{2}{*}{ TOTAL [6] } & $5033 / 5030$ & 6 & $79(1.5) / 77(1.5)$ & $52(1) / 25(0.5)$ & $99(2) / 92(1.8)$ \\
\hline & $5033 / 5030$ & 1 & & $33(0.65) / 16(0.32)$ & \\
\hline \multirow[t]{2}{*}{ TROFI $[45,46]$} & $59 / 61$ & 12 & NA & NA & $1(1.7) / 0$ \\
\hline & $71 / 70$ & 0 & NA & $0 / 1(1.4)$ & $0 / 0$ \\
\hline \multirow[t]{2}{*}{ VAMPIRE [47] } & $170 / 158$ & 8 & & & 0/1(0.6) \\
\hline & 178/171 & 0 & & & 0/1(0.6) \\
\hline Yin 2011 [48] & 73/91 & 12 & & & $3(4) / 6(6.6)$ \\
\hline
\end{tabular}




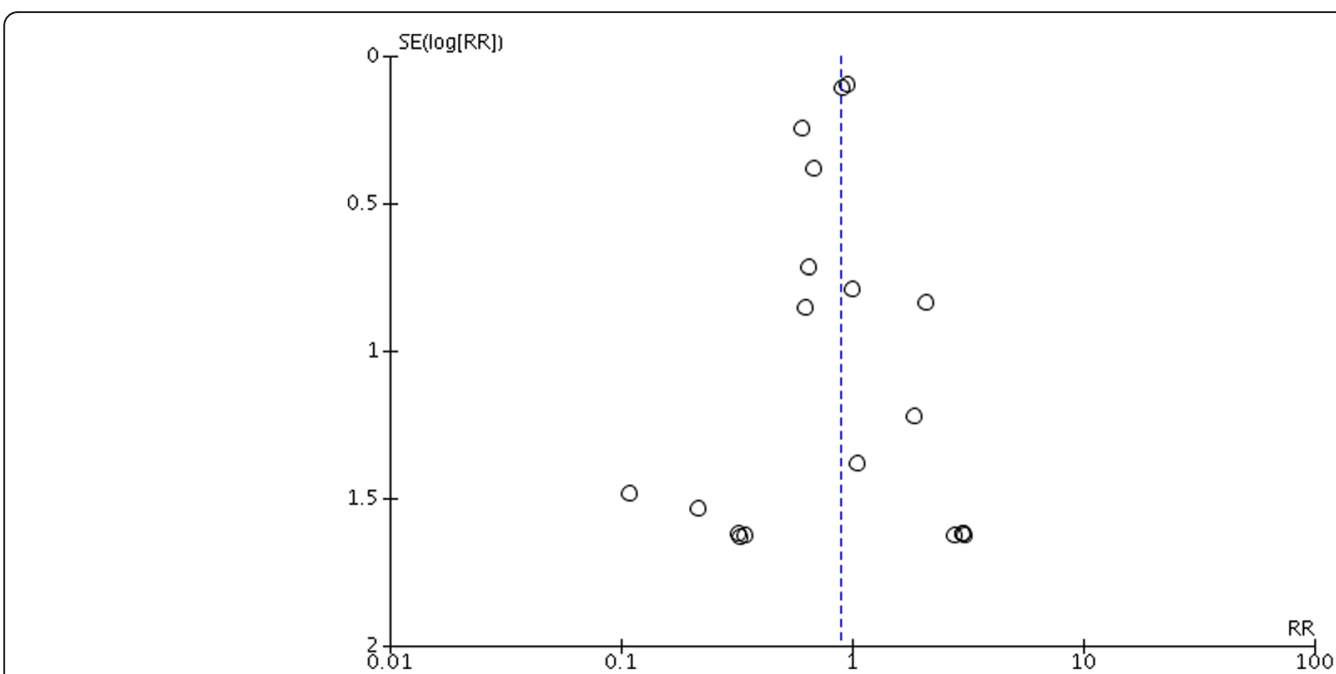

Fig. 9

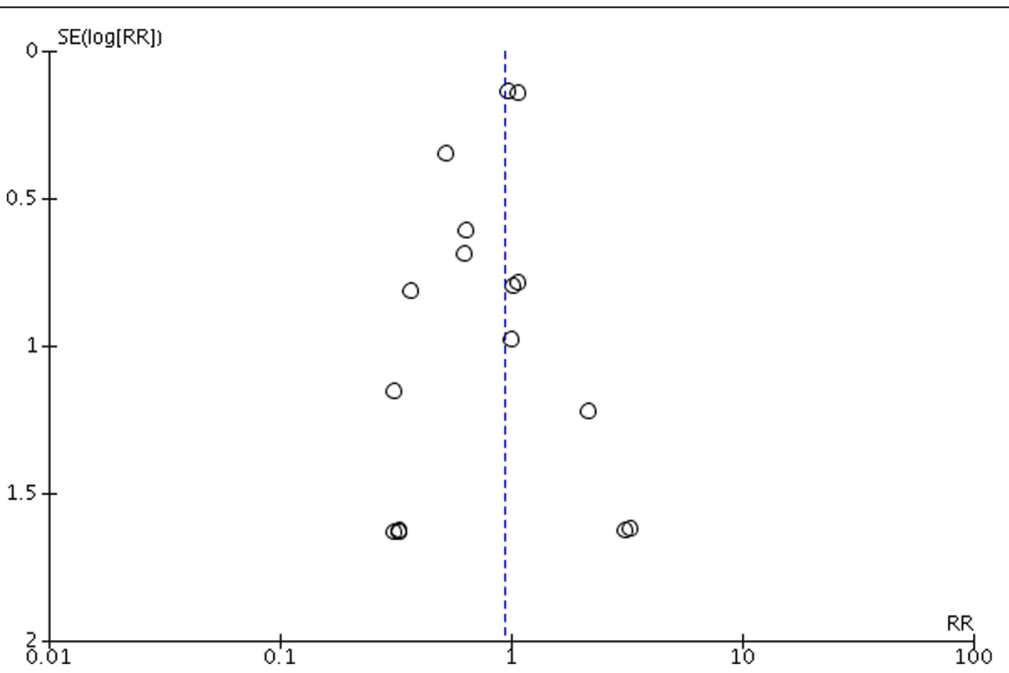

Fig. 10 


\section{Abbreviations}

AT, aspiration thrombectomy; CV, cardiovascular; CENTRAL, cochrane controlled trials register; Cls, confidential intervals; GRADE, grading of recommendations assessment development and evaluation; $\mathrm{MeSH}$, medical subject headings; MI, myocardial infarction; PRISMA, preferred reporting items for systematic reviews and meta-analyses statement; $\mathrm{PCl}$, primary percutaneous intervention; RCTs, randomized controlled trials; RevMan, review manager; RRs, risk ratios; STEMI, ST-segment elevation Ml; TOTAL, Trial of Routine Aspiration Thrombectomy with $\mathrm{PCl}$ versus $\mathrm{PCl}$ Alone in Patients with STEMI.

\section{Funding}

R El Dib received a Brazilian Research Council (CNPq) scholarship (CNPq 310953/2015-4)

\section{Authors' contributions}

Conceiving the review: GHG, FAS, POV and RED. Undertaking searches: JK. Screening search results: RED, EAS, HG, JK, POV. Organizing retrieval of papers: RED and EAS. Screening retrieved papers against inclusion criteria: RED, EAS, HG, JK and POV. Appraising quality of papers: RED, EAS, HG, JK and POV. Extracting data from papers: RED, EAS, HG, JK and POV. Writing to authors of papers for additional information: RED. Providing additional data about papers: RED. Obtaining and screening data on unpublished studies: RED and EAS. Managing data for the review: RED. Entering data into Review Manager (RevMan): RED. Analyzing RevMan statistical data: RED, FAS, GHG, POV. Interpreting data: RED, FAS, GHG, POV. Making statistical inferences: RED, FAS, GHG, POV. Writing the review: RED, FAS, GHG, POV. Taking responsibility for reading and checking the review before submission: RED, FAS, EAS, HG, JK, GHG, POV. All authors read and approved the final manuscript.

\section{Competing interests}

The authors declare that they have no competing interests.

\section{Author details}

${ }^{1}$ Department of Anaesthesiology, Botucatu Medical School, Unesp - Univ Estadual Paulista, São Paulo, Brazil. ${ }^{2}$ McMaster Institute of Urology, McMaster University, Hamilton, Ontario, Canada. ${ }^{3}$ Division of Cardiology, Department of Medicine, McMaster University, St. Joseph's Healthcare - 50 Charlton Avenue East, Hamilton, Ontario, Canada. ${ }^{4}$ Research Institute - Hospital do Coração (HCor), São Paulo, Brazil. ' Department of Pharmacy, Tanta Chest Hospital, Tanta, Egypt. ${ }^{6}$ Division of Cardiology and Heart Education And Research Training (HEART) Centre, Department of Medicine and Therapeutics, Prince of Wales Hospital, and Institute of Vascular Medicine, The Chinese University of Hong Kong, Shatin, Hong Kong. ${ }^{7}$ Department of Clinical Epidemiology and Biostatistics, McMaster University, Hamilton, Ontario, Canada. ${ }^{8}$ Department of Medicine, McMaster University, Hamilton, Ontario, Canada. ${ }^{9}$ Department of Medicine, Innlandet Hospital Trust-Division Gjøvik, Oppland, Norway.

${ }^{10}$ Institute for Health and Society, Faculty of Medicine, University of Oslo, Oslo, Norway.

\section{Received: 29 January 2016 Accepted: 14 May 2016}

\section{Published online: 02 June 2016}

\section{References}

1. Keeley EC, Boura JA, Grines CL. Primary angioplasty versus intravenous thrombolytic therapy for acute myocardial infarction: a quantitative review of 23 randomised trials. Lancet. 2003;361(9351):13-20.

2. Stone GW, Peterson MA, Lansky AJ, Dangas G, Mehran R, Leon MB. Impact of normalized myocardial perfusion after successful angioplasty in acute myocardial infarction. J Am Coll Cardiol. 2002;39(4):591-7.

3. Kumbhani DJ, Bavry AA, Desai MY, Bangalore $S$, Bhatt DL. Role of aspiration and mechanical thrombectomy in patients with acute myocardial infarction undergoing primary angioplasty: an updated meta-analysis of randomized trials. J Am Coll Cardiol. 2013;62(16):1409-18.

4. Kumbhani DJ, Bavry AA, Desai MY, Bangalore S, Byrne RA, Jneid $H$, et al. Aspiration thrombectomy in patients undergoing primary angioplasty: totality of data to 2013. Catheter Cardiovasc Interv. 2014;84(6):973-7.

5. Spitzer E, Heg D, Stefanini GG, Stortecky S, Rutjes AW, Räber L, Blöchlinger S, Pilgrim T, Jüni P, Windecker S. Aspiration Thrombectomy for Treatment of ST-segment Elevation Myocardial Infarction: a Meta-analysis of 26 Randomized Trials in 11943 Patients. Rev Esp Cardiol (Engl Ed). 2015;68(9):746-52.
6. Jolly SS, Cairns JA, Yusuf S, Meeks B, Pogue J, Rokoss MJ, Kedev S, Thabane L, Stankovic G, Moreno R, Gershlick A, Chowdhary S, Lavi S, Niemelä K, Steg PG, Bernat I, Xu Y, Cantor WJ, Overgaard CB, Naber CK, Cheema AN, Welsh RC, Bertrand OF, Avezum A, Bhindi R, Pancholy S, Rao SV, Natarajan MK, ten Berg JM, Shestakovska O, Gao P, Widimsky P, Džavík V. Randomized trial of primary PCI with or without routine manual thrombectomy. N Engl J Med. 2015;372(15):1389-98.

7. Ferreira-Gonzalez I, Busse JW, Heels-Ansdell D, Montori VM, Akl EA, Bryant DM, Alonso-Coello P, Alonso J, Worster A, Upadhye S, Jaeschke R, Schünemann HJ, Permanyer-Miralda G, Pacheco-Huergo V, Domingo-Salvany A, Wu P, Mills EJ, Guyatt GH. Problems with use of composite end points in cardiovascular trials: systematic review of randomised controlled trials. BMJ. 2007;334(7597):786.

8. Lim E, Brown A, Helmy A, Mussa S, Altman DG. Composite outcomes in cardiovascular research: a survey of randomized trials. Ann Intern Med. 2008;149(9):612-7.

9. Moher D, Liberati A, Tetzlaff J, Altman DG. Preferred reporting items for systematic reviews and meta-analyses: The PRISMA statement. BMJ. 2009;339:b2535.

10. Moher D, Cook DJ, Eastwood S, Olkin I, Rennie D, Stroup DF. Improving the quality of reports of meta-analyses of randomised controlled trials: the QUOROM statement. Quality of Reporting of Meta-analyses. Lancet. 1999;354(9193):1896-900.

11. Higgins JPT, Green S (editors). Cochrane Handbook for Systematic Reviews of Interventions Version 5.1.0 [updated March 2011]. The Cochrane Collaboration, 2011. Available from www.cochrane-handbook.org

12. Jolly SS, Cairns JA, Yusuf S, Meeks B, Gao P, Hart RG, Kedev S, Stankovic G, Moreno R, Horak D, Kassam S, Rokoss MJ, Leung RC, El-Omar M, Romppanen HO, Alazzoni A, Alak A, Fung A, Alexopoulos D, Schwalm JD, Valettas N, Džavík V. Stroke in the TOTAL trial: a randomized trial of routine thrombectomy vs. percutaneous coronary intervention alone in ST elevation myocardial infarction. Eur Heart J. 2015;36(35):2364-72.

13. Higgins JP, Altman DG, Gøtzsche PC, Jüni $P$, Moher D, Oxman AD, Savovic J, Schulz KF, Weeks L, Sterne JA. The Cochrane Collaboration's tool for assessing risk of bias in randomised trials. BMJ. 2011;343:d5928.

14. Guyatt GH, Busse JW. Modification of Cochrane Tool to assess risk of bias in randomized trials. http://distillercer.com/resources/.

15. Guyatt GH, Oxman AD, Vist GE, Kunz R, Falck-Ytter Y, Alonso-Coello P, Schünemann HJ. GRADE: an emerging consensus on rating quality of evidence and strength of recommendations. BMJ. 2008;336:924-6.

16. Guyatt GH, Oxman AD, Vist G, Kunz R, Brozek J, Alonso-Coello P, Montori V, Akl EA, Djulbegovic B, Falck-Ytter Y, Norris SL, Williams JW Jr, Atkins D, Meerpohl J, Schünemann HJ. GRADE guidelines: 4. Rating the quality of evidence-study limitations (risk of bias). J Clin Epidemiol. 2011;64:407-15.

17. Guyatt GH, Oxman AD, Kunz R, Brozek J, Alonso-Coello P, Rind D, Devereaux PJ, Montori VM, Freyschuss B, Vist G, Jaeschke R, Williams JW Jr, Murad MH, Sinclair D, Falck-Ytter Y, Meerpohl J, Whittington C, Thorlund K, Andrews J, Schünemann HJ. GRADE guidelines 6 . Rating the quality of evidence-imprecision. J Clin Epidemiol. 2011;64:1283-93.

18. Guyatt GH, Oxman AD, Kunz R, Woodcock J, Brozek J, Helfand M, AlonsoCoello P, Glasziou P, Jaeschke R, Akl EA, Norris S, Vist G, Dahm P, Shukla VK, Higgins J, Falck-Ytter Y, Schünemann HJ. GRADE guidelines: 7. Rating the quality of evidence-inconsistency. J Clin Epidemiol. 2011;64:1294-302.

19. Guyatt GH, Oxman AD, Kunz R, Woodcock J, Brozek J, Helfand M, Alonso-Coello P, Glasziou P, Jaeschke R, Akl EA, Norris S, Vist G, Dahm P, Shukla VK, Higgins J, Falck-Ytter Y, Schünemann HJ. GRADE guidelines: 8. Rating the quality of evidence-indirectness. J Clin Epidemiol. 2011;64:1303-10.

20. Guyatt GH, Oxman AD, Montori V, Vist G, Kunz R, Brozek J, Alonso-Coello P, Djulbegovic B, Atkins D, Falck-Ytter Y, Williams JW Jr, Meerpohl J, Norris SL, Akl EA, Schünemann HJ. GRADE guidelines: 5. Rating the quality of evidence-publication bias. J Clin Epidemiol. 2011;64:1277-82.

21. The Nordic Cochrane Centre. The Cochrane Collaboration. Review Manager (RevMan). 5.3. Copenhagen: The NordicCochrane Centre, The Cochrane Collaboration; 2011.

22. Orlic D, Ostojic M, Beleslin B, Borovic M, Tesic M, Milasinovic D, et al. The randomized physiologic assessment of thrombus aspiration in patients with ST-segment elevation acute myocardial infarction trial (PATA STEMI) [abstract]. Eur Heart J. 2014;35:Abstract Supplement, 45

23. Woo SI, Park SD, Kim DH, Kwan J, Shin SH, Park KS, Kim SH, Ko KY, Hwang TH, Yoon GS, Choi WG, Kim SH. Thrombus aspiration during primary percutaneous coronary intervention for preserving the index of microcirculatory resistance: $\mathrm{A}$ randomised study. Eurolntervention. 2014;9(9):1057-62. 
24. Shehata M. Impact of successful manual thrombus aspiration during primary $\mathrm{PCl}$ in diabetic patients: Angiographic and clinical follow-up [abstract]. Catheter Cardiovasc Interv. 2014;83:S3.

25. Shehata M. Angiographic and clinical impact of successful manual thrombus aspiration in diabetic patients undergoing primary PCI. Int J Vasc Med 2014b; 263926 doi:10.1155/2014/263926.

26. Lagerqvist B, Fröbert O, Olivecrona GK, Gudnason T, Maeng M, Alström P, Andersson J, Calais F, Carlsson J, Collste O, Götberg M, Hårdhammar P, loanes D, Kallryd A, Linder R, Lundin A, Odenstedt J, Omerovic E, Puskar V, Tödt T, Zelleroth E, Östlund O, James SK.. Outcomes 1 year after thrombus aspiration for myocardial infarction. N Engl J Med. 2014;371(12):1111-20.

27. Frobert O, Lagerqvist B, Olivecrona GK, Omerovic E, Gudnason T, Maeng M, Aasa $M$, Angerås $O$, Calais $F$, Danielewicz $M$, Erlinge $D$, Hellsten $L$, Jensen $U$, Johansson AC, Kåregren A, Nilsson J, Robertson L, Sandhall L, Sjögren I, Ostlund O, Harnek J, James SK. Thrombus aspiration during st-segment elevation myocardial infarction. N Engl J Med. 2013;369:1587-97.

28. Turgeman Y, Bushari LI, Antonelli D, Feldman A, Yahalom M, Bloch L, Suleiman K. Catheter Aspiration after Every Stage during Primary Percutaneous Angioplasty, ADMIT Trial. Intl J Angiol. 2014;23(1):29-40.

29. Bulum J, Ernst A, Strozzi M. The impact of successful manual thrombus aspiration on in-stent restenosis after primary $\mathrm{PCl}$ : Angiographic and clinical follow-up. Coron Artery Dis. 2012;23:487-91.

30. Chao CL, Hung CS, Lin YH, Lin MS, Lin LC, Ho YL, Liu CP, Chiang CH, Kao HL. Time-dependent benefit of initial thrombosuction on myocardial reperfusion in primary percutaneous coronary intervention. Int J Clin Pract. 2008;62:555-61.

31. De Luca L, Sardella G, Davidson CJ, De Persio G, Beraldi M, Tommasone T, Mancone M, Nguyen BL, Agati L, Gheorghiade M, Fedele F. Impact of intracoronary aspiration thrombectomy during primary angioplasty on left ventricular remodeling in patients with anterior ST elevation myocardial infarction. Heart. 2006;92:951-7

32. Sardella G, Mancone M, Bucciarelli-Ducci C, Agati L, Scardala R, Carbone I, et al. Thrombus aspiration during primary percutaneous coronary intervention improves myocardial reperfusion and reduces infarct size: The EXPIRA (thrombectomy with export catheter in infarct-related artery during primary percutaneous coronary intervention) prospective, randomized trial. J Am Coll Cardiol. 2009;53:309-15.

33. Sardella G, Mancone M, Canali E, Di Roma A, Benedetti G, Stio R, Badagliacca R, Lucisano L, Agati L, Fedele F. Impact of thrombectomy with export catheter in infarct-related artery during primary percutaneous coronary intervention (EXPIRA trial) on cardiac death. Am J Cardiol. 2010;106:624-9.

34. Chevalier B, Gilard M, Lang I, Commeau P, Roosen J, Hanssen M, Lefevre T, Carrié D, Bartorelli A, Montalescot G, Parikh K. Systematic primary aspiration in acute myocardial percutaneous intervention: A multicentre randomised controlled trial of the Export aspiration catheter. Eurolntervention. 2008:4:222-8.

35. Hoole SP, Jaworski C, Brown AJ, McCormick LM, Agrawal B, Clarke SC, West NE. Serial assessment of the index of microcirculatory resistance during primary percutaneous coronary intervention comparing manual aspiration catheter thrombectomy with balloon angioplasty (IMPACT study): a randomised controlled pilot study. Open Heart. 2015;2(1):e000238.

36. Stone GW, Maehara A, Witzenbichler B, Godlewski J, Parise H, Dambrink JH, Ochala A, Carlton TW, Cristea E, Wolff SD, Brener SJ, Chowdhary S, El-Omar M, Neunteufl T, Metzger DC, Karwoski T, Dizon JM, Mehran R, Gibson CM. Intracoronary abciximab and aspiration thrombectomy in patients with large anterior myocardial infarction: The INFUSE-AMI randomized trial. JAMA. 2012:307:1817-26.

37. Stone GW, Witzenbichler B, Godlewski J, Dambrink JH, Ochala A, Chowdhary $\mathrm{S}$, et al. Intralesional abciximab and thrombus aspiration in patients with large anterior myocardial infarction: One-year results from the INFUSE-AMI trial. Circ Cardiovasc Interv. 2013;6:527-34.

38. Liu CP, Lin MS, Chiu YW, Lee JK, Hsu CN, Hung CS, Kao HL. Additive benefit of glycoprotein $\mathrm{Ib} / \mathrm{llla}$ inhibition and adjunctive thrombus aspiration during primary coronary intervention: results of the Initial Thrombosuction and Tirofiban Infusion (ITTI) trial. Int J Cardiol. 2012;156(2):174-9.

39. Kaltoft A, Bøttcher M, Nielsen SS, Hansen HH, Terkelsen C, Maeng M, Kristensen J, Thuesen L, Krusell LR, Kristensen SD, Andersen HR, Lassen JF, Rasmussen K, Rehling M, Nielsen T, Bøtker HE. Routine thrombectomy in percutaneous coronary intervention for acute ST-segment-elevation myocardial infarction: A randomized, controlled trial. Circulation. 2006;114:40-7.
40. Liistro F, Grotti S, Angioli P, Falsini G, Ducci K, Baldassarre S, Sabini A, Brandini R, Capati E, Bolognese L. Impact of thrombus aspiration on myocardial tissue reperfusion and left ventricular functional recovery and remodeling after primary angioplasty. Circ Cardiovasc Interv. 2009;2:376-83.

41. Burzotta F, Trani C, Romagnoli E, Mazzari MA, Rebuzzi AG, De Vita M, Garramone B, Giannico F, Niccoli G, Biondi-Zoccai GG, Schiavoni G, Mongiardo R, Crea F. Manual thrombus-aspiration improves myocardial reperfusion: The randomized evaluation of the effect of mechanical reduction of distal embolization by thrombus-aspiration in primary and rescue angioplasty (REMEDIA) trial. J Am Coll Cardiol. 2005;46:371-6.

42. Sim DS, Ahn Y, Kim YH, Lee D, Seon HJ, Park KH, Yoon HJ, Yoon NS, Kim KH, Hong YJ, Park HW, Kim JH, Jeong MH, Cho JG, Park JC. Effect of manual thrombus aspiration during primary percutaneous coronary intervention on infarct size: Evaluation with cardiac computed tomography. Int J Cardio. 2013;168:4328-30

43. Svilaas T, Vlaar PJ, van der Horst IC, Diercks GF, de Smet BJ, van den Heuvel AF, Anthonio RL, Jessurun GA, Tan ES, Suurmeijer AJ, Zijlstra F. Thrombus aspiration during primary percutaneous coronary intervention. N Engl J Med. 2008;358:557-67.

44. Vlaar PJ, Svilaas T, van der Horst IC, Diercks GF, Fokkema ML, de Smet BJ, van den Heuvel AF, Anthonio RL, Jessurun GA, Tan ES, Suurmeijer AJ, Zijlstra $F$. Cardiac death and reinfarction after 1 year in the thrombus aspiration during percutaneous coronary intervention in acute myocardial infarction study (tapas): A 1-year follow-up study. Lancet. 2008;371:1915-20.

45. Onuma Y, Thuesen L, van Geuns RJ, van der Ent M, Desch S, Fajadet J, Christiansen E, Smits P, Holm NR, Regar E, van Mieghem N, Borovicanin V, Paunovic D, Senshu K, van Es GA, Muramatsu T, Lee IS, Schuler G, Zijlstra F, Garcia-Garcia HM, Serruys PW. Randomized study to assess the effect of thrombus aspiration on flow area in patients with ST-elevation myocardial infarction: an optical frequency domain imaging study—TROFI trial. European Heart J. 2013;34:1050-60.

46. Garcia-Garcia HM, Muramatsu T, Nakatani S, Lee IS, Holm NR, Thuesen L, van Geuns RJ, van der Ent M, Borovicanin V, Paunovic D, Onuma Y, Serruys PW. Serial optical frequency domain imaging in STEMI patients: the follow-up report of TROFI study. European Heart J - Cardiovascular Imaging. 2014;15(9):987-95.

47. Ikari Y, Sakurada M, Kozuma K, Kawano S, Katsuki T, Kimura K, Suzuki T, Yamashita T, Takizawa A, Misumi K, Hashimoto H, Isshiki T. Upfront thrombus aspiration in primary coronary intervention for patients with ST-segment elevation acute myocardial infarction: Report of the VAMPIRE (vacuum aspiration thrombus removal) trial. JACC Cardiovasc Interv. 2008;1:424-31.

48. Yin D, Zhu H, Zhou X, Huang R, Wang J, Zheng Z. Thrombus aspiration before angiography during percutaneous coronary intervention in acute myocardial infarction. J Dalian Med Univ. 2011;33:235-9.

49. D'Ascenzo F, Barbero U, Moretti C, Palmerini T, Della Riva D, Mariani A Omedè P, DiNicolantonio JJ, Biondi-Zoccai G, Gaita F. Percutaneous coronary intervention versus coronary artery bypass graft for stable angina: meta-regression of randomized trials. Contemp Clin Trials. 2014;38(1):51-8.

50. Elgendy IY, Huo T, Bhatt DL, Bavry AA. Is Aspiration Thrombectomy Beneficial in Patients Undergoing Primary Percutaneous Coronary Intervention? Meta-Analysis of Randomized Trials. Circ Cardiovasc Interv. 2015;8(7).

51. Barkagan M, Steinvil A, Berchenko Y, Finkelstein A, Keren G, Banai S, Halkin A. Impact of routine manual aspiration thrombectomy on outcomes of patients undergoing primary percutaneous coronary intervention for acute myocardial infarction: A meta-analysis. Int J Cardiol. 2016;204:189-95.

\section{Submit your next manuscript to BioMed Central and we will help you at every step:}

- We accept pre-submission inquiries

- Our selector tool helps you to find the most relevant journal

- We provide round the clock customer support

- Convenient online submission

- Thorough peer review

- Inclusion in PubMed and all major indexing services

- Maximum visibility for your research

Submit your manuscript at www.biomedcentral.com/submit 